\title{
IMPACT OF EXPERIMENTAL FREEZE-THAW EVENTS ON BACTERIAL COMMUNITY DYNAMICS IN PETROLEUM POLLUTED TEMPERATE SOILS
}

\author{
OKONKWO, C. J. ${ }^{1}-$ LIU, N. ${ }^{1,2^{*}}-$ LI, J. ${ }^{1}-$ AHMED, A. ${ }^{1}$ \\ ${ }^{1}$ Key Laboratory of Groundwater Resources and Environment, Ministry of Education, College \\ of New Energy and Environment, Jilin University, Changchun 130021, China \\ ${ }^{2}$ Institute of Groundwater and Earth Science, Jinan University, Guangzhou City 510632, China \\ *Corresponding author \\ email: liuna@jlu.edu.cn
}

(Received $1^{\text {st }}$ Sep 2021; accepted $28^{\text {th }}$ Oct 2021)

\begin{abstract}
Soil bacteria are important drivers of biogeochemical cycles and they participate in the degradation of contaminants in petroleum polluted soils. Here, we investigated the influence of freezethaw events on bacterial community structure and diversity in petroleum-polluted temperate soils. Four temperate soils from Northern China (clean (CS), short-term diesel fuel-pollution (SS1), short-term crude oil-pollution (SS2), and weathered petroleum-pollution (PS)) were subjected to freeze-thaw events with a temperature range of -20 to $+20{ }^{\circ} \mathrm{C}$ for 47 days. In this study, polymerase chain reaction and highthroughput sequencing of soil microbial DNA were applied to investigate the compositions of microorganisms including alpha and beta diversity in the soils. Results showed that after the freezing and thawing treatments, Proteobacteria was still the predominant phylum but its relative abundance in the clean and short-term polluted soils changed whereas it remained constant in PS. The bacterial community compositions in the short-term polluted soils were the most affected by freeze-thaw events. Overall, our results established that the dissimilarities in bacterial communities in the soils were more of a result of their contamination profiles than their exposure to freeze-thaw events.
\end{abstract}

Keywords: temperature variation, oil pollution, $\alpha$-diversity, beta-diversity

\section{Introduction}

Petroleum pollution represents a major source of soil and groundwater contamination in the cold temperate regions (Aislabie et al., 2004). The impact of contamination is usually more severe in colder environments as the ecosystems present are generally more sensitive to temperature variations (Bell et al., 2012). Consequently, the remediation of petroleum contaminants in cold environments faces challenges such as nutrient deficiency and slower degradation rates due to lower surface temperatures (Yang et al., 2019). Hence, the successful bioremediation of petroleum-contaminated sites in most cold climate regions requires an in-depth understanding of the diversity and dynamics of the indigenous petroleum degrading microorganisms and their responses to changing temperature regimes (Gavazov et al., 2017).

The freeze-thaw event in soils is a common but complicated process which occurs in temperate and cold climate soils (Ren et al., 2018). Most temperate environments experience significant annual variations in freeze thaw cycles with seasonal transitions occurring about twice in a year (Guoqing et al., 2014). Freeze-thaw cycles (FTCs) can be categorized into annual and diurnal FTCs with the frequency of the latter changing under climate warming scenarios (Wang et al., 2017). Both the annual and diurnal FTCs exert great influence on soil physicochemical and biological properties (Børresen et al., 2007). Their influence is mainly due to the creation of different soil microenvironments 
especially in terms of unfrozen water availability in the soil matrices and nutrient release (Henry, 2007; Olsson et al., 2003). Skogland and colleagues (1988) estimated that a single FTC resulted in respiratory losses equivalent to $15 \%$ microbial mass carbon. In another study by Schimel et al. (2007), they observed that one FTC could release carbon to the atmosphere corresponding to as much as $25 \%$ of the net annual primary production in an Alaskan tussock tundra region. This release of carbon is expected to exacerbate climate change (Kumar et al., 2013).

In a changing climate, the temperate regions including the Eurasia drylands where Northern China is situated are expected to undergo substantial warming with a projected increase in average air temperature of $2-4{ }^{\circ} \mathrm{C}$ in this century (IPCC, 2007; Schmidhuber and Tubiello, 2007). Climate modelling studies have also confirmed that reduced snow cover in winter and consequentially decreased insulation of soils against freezing results in increased freeze-thaw frequency (Christensen et al., 2007; Kimoto, 2005). Such increases in the frequency of freeze-thaw processes are of ecological interest because of their impacts on soil microbial communities and nutrient transformation especially in petroleum polluted environments. The distribution of microbes in petroleum polluted soils has been well interpreted (Wu et al., 2016). For instance, in oil-contaminated soils, the microbial community composition has been shown to shift in favour of the petroleum hydrocarbon degraders (Siles and Margesin, 2018). Previous studies conducted using high-throughput sequencing technology have shown that the changes in soil microbial population and diversity in oil-polluted sites are higher compared to clean, uncontaminated soil, and their metabolic activities were susceptible to sensitivity by the external environment (Trellu et al., 2016; Igun et al., 2019). It is essential to mention that the nature and duration of contamination (short or long term) could be a critical factor in determining how microbial communities respond as tolerance may be developed over time. Additionally, as these polluted soils undergo episodes of freezing and thawing induced by climate change, the associated temperature variations can further influence the distribution characteristics of microbial communities occurring in ecosystems where organisms may be at the limit of their physiological tolerance. Therefore, monitoring the responses of soil microbes in petroleum polluted soils to variations in simulated freeze/thaw temperature regimes would provide useful information that can be applied in optimizing the current or designing new bioremediation strategies for contaminated sites in the temperate region as it experiences climate change.

Although some studies have been conducted on the effects of FTCs on microbial communities in soils from temperate regions (Ren et al., 2018; Han et al., 2018; Juan et al., 2018) detailed datasets on the effects of freeze-thaw events on microbial communities in petroleum polluted soils are still lacking. Our research here addressed the following questions: Can the freeze-thaw processes triggered by climate change affect the distribution characteristics of bacterial communities in weathered petroleum polluted soils and ones affected by short-term pollution? What happens to the petroleum hydrocarbon degraders in short-term and weathered petroleum polluted soils when they are subjected to an hypothetical freezing and thawing rate of $2{ }^{\circ} \mathrm{C}$ per day similar to the global climate change projection for Asia (Li et al., 2018; Lin et al., 2018)? We hypothesized that freeze-thaw events can have a direct impact on the diversity, abundance, and responsiveness of soil bacterial communities in short-term and weathered petroleum contaminated soils. To test this hypothesis, a controlled soil incubation experiment to simulate freeze-thaw conditions $\left(-20\right.$ to $\left.20{ }^{\circ} \mathrm{C}\right)$ was conducted 
using four soils (clean soil, short-term diesel polluted soil, short-term crude oil-polluted soil and weathered petroleum polluted soil). Polymerase chain reaction and highthroughput sequencing of soil microbial DNA were applied to investigate the compositions of microorganisms and alpha diversity in the soils at ten temperature points. Our objectives were (1) to compare differences in the abundance and diversity of bacterial communities across the four soil types during freezing and thawing periods. (2) to investigate the microbial community dynamics in each soil as a function of contamination type.

\section{Materials and methods}

\section{Soil sampling and analysis}

The weathered petroleum-polluted soil (PS) sample was collected near the petroleum well (sampling depth $<20 \mathrm{~cm}$ ) which had been exploited for about twenty years in Songyuan city of Jilin Province, China $\left(45.1375^{\circ} \mathrm{N}, 124.8348^{\circ}\right.$ E) while the clean natural soil (CS) was collected from a site in Changchun city, Jilin Province, China (39 ${ }^{\circ}$ $\left.7 ' 55^{\prime \prime} \mathrm{N}, 117^{\circ} 11^{\prime} 53^{\prime \prime} \mathrm{E}\right)$, with no history of petroleum contamination and also confirmed by GC-MS analysis of C10 - C36 petroleum hydrocarbons. The methods of sampling, collection and transportation were according to the description of $\mathrm{Wu}$ et al. (2016). Both sampling sites (situated in Jilin Provinces) are located in a cold temperate continental monsoon climate with an average precipitation of $500-650 \mathrm{~nm}$, an annual average temperature of $1-2{ }^{\circ} \mathrm{C}$, and an average frost-free period of 120-140 days (Guo et al., 2013).

In this study, two types of short-term petroleum polluted soil were used, SS1 and SS2 represent diesel-oil amended and crude-oil amended soil, respectively. SS1 was prepared by adding diesel oil to the clean soil at a percentage of $10 \%$ (volume/weight) while for SS2, crude oil was added to clean soil at a percentage of $10 \%$ (volume/weight) and thoroughly homogenized with a glass rod. The amended soils (short-term petroleum polluted soils) were left at room temperature for two days before subjecting them to the freeze-thaw cycles. The physical and chemical properties of the soils have been previously characterized in our earlier published study (Okonkwo et al., 2021).

\section{Freeze-thaw microcosm}

The soil samples (an equivalent of $150 \mathrm{~g}$ of dry soil) were incubated in a specialised temperature and humidity programmable machine (HD-GDJS, China). The samples were incubated for 47 days, starting with a pre-incubation step at $+20^{\circ} \mathrm{C}$ for $48 \mathrm{~h}$, then a gradual decrease to $-20{ }^{\circ} \mathrm{C}$ over 20 days, followed by $-20{ }^{\circ} \mathrm{C}$ for five days and a thawing phase with increasing temperature over 20 days to $+20^{\circ} \mathrm{C}$ thereby providing a simulation of repeated freezing and thawing periods (9). The freezing and thawing rates were hypothetically set at $2{ }^{\circ} \mathrm{C}$ per day and the experiment involved four extended phases: pre-incubation phase $\left(20^{\circ} \mathrm{C}\right)$, freezing phase $\left(10{ }^{\circ} \mathrm{C}\right.$ to $\left.-20^{\circ} \mathrm{C}\right)$, transition phase $\left(-20^{\circ} \mathrm{C}\right)$ and thawing phase $\left(-10^{\circ} \mathrm{C}\right.$ to $\left.20^{\circ} \mathrm{C}\right)$ (Fig. 1). Samples were obtained between five-day intervals at $+20,+10,0,-10,-20{ }^{\circ} \mathrm{C}$ during the freezing phase; these samples

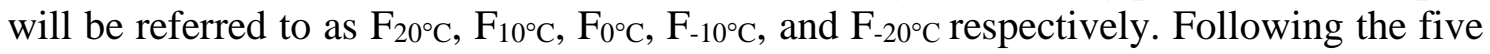
days at $-20{ }^{\circ} \mathrm{C}$, samples were obtained at five-day intervals $-20,-10,0,+10,+20{ }^{\circ} \mathrm{C}$ in

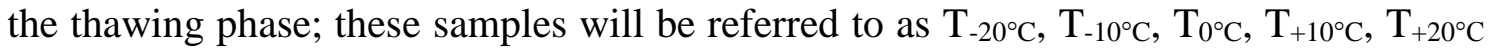
respectively. 
At each of the ten sampling points, two replicates were collected, labelled and immediately stored at $-80^{\circ} \mathrm{C}$ until DNA extraction.

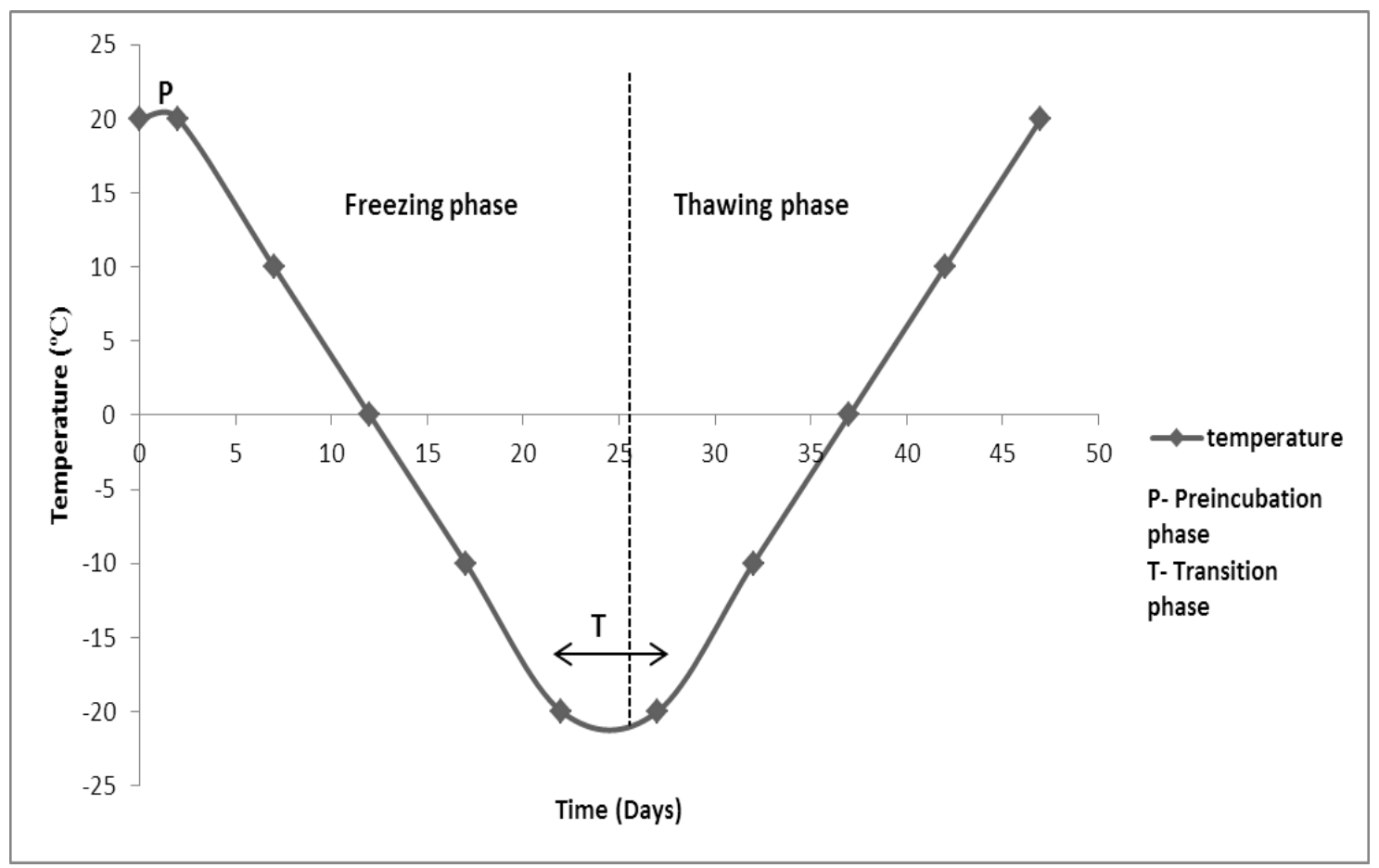

Figure 1. Temperature regimes for the freeze-thaw experiment

\section{Microbial community analyses}

Microbial community in the soil samples at each of the ten previously mentioned time points was determined by the following steps;

A total of 40 DNA samples were obtained from the four different soil groups (CS, PS, SS1 and SS2) after the freeze-thaw experiment. The DNA samples were labelled F1 to F40 for easy identification (Table 1). Soil DNA was extracted by OMEGA E.Z.N.A ${ }^{\mathrm{TM}}$ Mag-Bind Soil DNA kit (Omega Bio-tek, Inc, GA, USA) according to manufacturer's instruction. DNA quality was assayed on $1 \%$ agarose gel and the quantity of DNA was determined by Qubit 3.0 DNA detection kit (Invitrogen, Carlsbad, CA, USA). A total of $10-20 \mathrm{ng}$ of DNA was used to generate amplicons using MetaVx ${ }^{\mathrm{TM}}$ Library Preparation kit (GENEWIZ, Inc, NJ, USA).

The microbial diversity was evaluated by amplicon-based metagenomic sequencing using the primers NOBAR_341F (5'-CCTACGGGNGGCWGCAG-3') and NOBAR_805R (5'-GACTACHVGGGTATCTAATCC-3') for the bacterial V3-V4 region of the 16S rRNA gene (White et al., 1990; Cisneros-de la Cueva et al., 2016). Next-generation sequencing was conducted on an Illumina Miseq Platform (Illumina, San-Diego, USA) at Sangon Biotech Co., Ltd., Shanghai, China.

\section{Statistical and bioinformatics analyses}

All merged raw sequences were trimmed using the Quantitative Insights into Microbial Ecology (QIIME) toolkit v.1.7.0 (Caporaso et al., 2010). After ambiguous bases containing " $\mathrm{N}$ " were trimmed, joined sequences with lengths between 240 and 
260 base pairs were subjected to chimera removal by U-Chime (Edgar et al., 2011) in Mothur (v.1.30.1). Lastly, OTU clustering was performed using UCLUST at a similarity level of 97\% (Wang et al., 2007), and taxonomic groups were assigned using RDP Classifier (Jia et al., 2017) with a minimal 50\% confidence estimate. The Mothur software (version v.1.30.1) was used to estimate coverage according to Good's estimator. Alpha $(\alpha)$-diversity metrics (observed species (OTUs), Chao1 richness, Shannon's Index) were calculated for soil samples (at various freeze thaw incubation temperature points) using Mothur while Beta $(\beta)$-diversity metrics were calculated using weighted UniFrac metrics, unweighted UniFrac measures and Bray-Curtis dissimilarity matrix. The $\beta$-diversity (unweighted UniFrac and weighted UniFrac distances) were visualized using Prinicipal Co-ordinate Analysis (PCoA) ordination method (Shankar et al., 2017). Venn diagram was constructed using $\mathrm{R}$ statistical package (R Core Team, 2014) to visualise unique species present in the clean and polluted soils. The taxa shifts along with different incubation temperatures in the four soil groups were presented in pie charts based on the percent relative abundances of the top abundant bacteria at the genus and phylum levels respectively.

Table 1. Sample identification codes for microbial community analyses

\begin{tabular}{|c|c|c|c|c|c|c|c|}
\hline Code & $\begin{array}{c}\text { Soil } \\
\text { sample }\end{array}$ & \begin{tabular}{|c|} 
Sampling \\
temperature $\left({ }^{\circ} \mathrm{C}\right)$
\end{tabular} & Phase & Code & $\begin{array}{c}\text { Soil } \\
\text { sample }\end{array}$ & $\begin{array}{c}\text { Sampling } \\
\text { temperature }\left({ }^{\circ} \mathrm{C}\right)\end{array}$ & Phase \\
\hline $\mathrm{F} 1$ & $\mathrm{CS}$ & 20 & Pre-incubation & F21 & $\mathrm{SS} 2$ & 20 & Pre-incubation \\
\hline $\mathrm{F} 2$ & $\mathrm{CS}$ & 10 & Freezing & F22 & $\mathrm{SS} 2$ & 10 & Freezing \\
\hline F3 & $\mathrm{CS}$ & 0 & Freezing & F23 & SS2 & 0 & Freezing \\
\hline $\mathrm{F} 4$ & $\mathrm{CS}$ & -10 & Freezing & $\mathrm{F} 24$ & $\mathrm{SS} 2$ & -10 & Freezing \\
\hline F5 & $\mathrm{CS}$ & -20 & Freezing & $\mathrm{F} 25$ & $\mathrm{SS} 2$ & -20 & Freezing \\
\hline F6 & $\mathrm{CS}$ & -20 & Transition & F26 & $\mathrm{SS} 2$ & -20 & Transition \\
\hline F7 & $\mathrm{CS}$ & -10 & Thawing & F27 & $\mathrm{SS} 2$ & -10 & Thawing \\
\hline F8 & $\mathrm{CS}$ & 0 & Thawing & F28 & SS2 & 0 & Thawing \\
\hline F9 & $\mathrm{CS}$ & 10 & Thawing & F29 & SS2 & 10 & Thawing \\
\hline F10 & $\mathrm{CS}$ & 20 & Thawing & F30 & $\mathrm{SS} 2$ & 20 & Thawing \\
\hline F11 & SS1 & 20 & Pre-incubation & F31 & PS & 20 & Pre-incubation \\
\hline F12 & $\mathrm{SS} 1$ & 10 & Freezing & F32 & PS & 10 & Freezing \\
\hline F13 & SS1 & 0 & Freezing & F33 & PS & 0 & Freezing \\
\hline F14 & SS1 & -10 & Freezing & F34 & PS & -10 & Freezing \\
\hline F15 & SS1 & -20 & Freezing & F35 & PS & -20 & Freezing \\
\hline F16 & SS1 & -20 & Transition & F36 & PS & -20 & Transition \\
\hline F17 & $\mathrm{SS} 1$ & -10 & Thawing & F37 & PS & -10 & Thawing \\
\hline F18 & $\mathrm{SS} 1$ & 0 & Thawing & F38 & PS & 0 & Thawing \\
\hline F19 & $\mathrm{SS} 1$ & 10 & Thawing & F39 & PS & 10 & Thawing \\
\hline $\mathrm{F} 20$ & SS1 & 20 & Thawing & $\mathrm{F} 40$ & PS & 20 & Thawing \\
\hline
\end{tabular}

CS: Clean soil, SS1: Short-term diesel-oil polluted soil, SS2: Short-term crude-oil polluted soil, PS: Weathered petroleum polluted soil

\section{Prediction and analysis of gene functions of the bacterial microbiota}

PICRUSt software package was used to predict predictive functional profiling of microbial communities using 16S rRNA marker gene sequences (Langille et al., 2013). 
The metagenomic functions and pathways are predicted against COG and KEGG pathways. Heatmap was generated using the pheatmap and Gplots packages in R.

\section{Results and discussion}

\section{Bacterial community compositions in the clean, short-term and weathered petroleum polluted soils}

Illumina MiSeq sequencing of the 40 soil samples after the FTCs produced 2143348 raw and 2069096 quality sequence reads. OTU clustering at a similarity level of $97 \%$ resulted in 133264 OTUs. The obtained bacterial sequences were classified into 46 known phyla.

According to the pie charts, the relative abundance of the genus differed dramatically among the clean, short-term and weathered polluted soils during the preincubation phase (Fig. 2a-d). Arthrobacter (7.11\%), Janthinobacterium, $(8.40 \%)$ and Flavobacterium (7.96\%) were the dominant groups in the clean soil group (Fig. $2 a$ ). The dominant genus groups in the SS1 were Pseudomonas (13.60\%), Massilia (7.19\%), and Arthrobacter (5.96\%) (Fig. 2b). Thermomonas, Arenimonas and Aquabacterium accounted for $>50 \%$ of the total bacterial community in the SS2 (Fig. 2c) while Pseudomonas (6.92\%), Rhodoferax (5.97\%), Lutibacter (3.96\%), and Thiobacillus $(3.75 \%)$ were the predominant genus groups in PS (Fig. 2d). In this study, although the pre-incubation phase lasted for $48 \mathrm{~h}$, it is interesting to note the rapid changes that occurred in the short-term polluted soils within the short time frame. There was a distinct redistribution in the relative abundance of the bacterial community in the short-term polluted soils SS1 and SS 2 with community composition shifting in favour of the petroleum hydrocarbon degraders Pseudomonas and Massilia in SS1 while Thermomonas and Arenimonas were the dominant petroleum hydrocarbon degraders in SS2. This finding is consistent with previous studies in which petroleum contamination led to the selective enrichment of oildegrading bacteria while others were suppressed (Jia et al., 2017; Wyszkowska and Kucharski, 2005). We further observed that the selective enrichment of petroleum degraders in SS1 and SS2 differed with respect to the oil types i.e., diesel fuel and crude oil suggesting that there may be a strong association between the predominant oil-degraders found in a soil and nature of oil contaminant present in that soil. A reasonable explanation for this occurrence is that petroleum products often differ in their abilities to disrupt of soil trophic and aerobic conditions and contribute to organic carbon pools (Borowik et al., 2019). The class level results (Fig. Al) in the short-term polluted soils further highlights the difference in selective enrichment of bacterial classes as a function of oil contamination type. The diesel amended soil SS1 was dominated by Betaproteobacteria while Gammaproteobacteria exhibited highest abundance in the crude oil amended soil SS2 during this phase. The increase in the abundance of Beta- and Gammaproteobacterial classes in the short-term polluted soils is in line with observations made in previous studies on bacterial shifts upon contamination with petroleum (Korenblum et al., 2012; Baek et al., 2007). Hence, pollution of soil with different petroleum products may not produce similar changes in the soil microbiome.

At the phylum level, Proteobacteria was the dominant group in the clean and polluted soils during this phase of the study (Fig. A2a-d). They accounted for $48.56 \%$ in the clean soil, for $53.51 \%, 88.98 \%$ and $74.84 \%$ in polluted soils SS1, SS2 and PS 
respectively. The short-term pollution of soil with petroleum products elicited notable changes in the abundance of the dominant phylum. Proteobacteria in SS1 and SS2 was higher by $4.95 \%$ and $40.42 \%$ respectively than in the clean soil CS. This finding was consistent with previous reports on cold temperate soils where Proteobacteria was the predominant phylum (Shen et al., 2014; Sun et al., 2015). Borowik et al. (2019) reported that Proteobacteria was higher by $35.3 \%$ in the soil exposed to diesel contamination compared to the control soil. The difference in relative abundance of Proteobacteria between the clean and polluted soils could be attributed to presence of alternative carbon sources. In addition, Wu et al. (2019) and Liu et al. (2020) found that the relative abundance of Proteobacteria in soil was positively correlated with hydrocarbon content. Hence, the higher hydrocarbon contents in the polluted soils might partly account for the increase in Proteobacteria in SS1, SS2 and PS.

During the freezing phase $\left(\mathrm{F} 10^{\circ} \mathrm{C}\right.$ to $\left.\mathrm{F}-20^{\circ} \mathrm{C}\right)$, the identified sequences from the different soil types were affiliated with 47 bacterial genera (Figs. 3-6). At the beginning of the freezing phase (Fig. 3a-d), the bacterial genera Arthrobacter (8.67\%) and Janthinobacterium $(8.09 \%)$ were predominant in the clean soil. The short-term polluted soil SS1 was characterized by lower relative abundance of Pseudomonas (12.51\%) whereas SS2 showed higher relative abundance of Thermomonas (55.89\%) when compared to their population during the pre-incubation phase. Consistent decrease in temperature at the hypothetical rate of $2{ }^{\circ} \mathrm{C}$ per day resulted in decreased relative abundance of the predominant bacterial genera in SS1 while the abundance of Thermomonas in SS2 increased in response to lower temperatures (Figs. 3c, 4c, 5c and $6 c$ ). Thermomonas is a gamma proteobacterium that has been identified as psychrotolerant with a wide growth range from $18-50{ }^{\circ} \mathrm{C}$ (52). In this study, Thermomonas was able to adapt to sub-zero freezing temperatures and selective pressure exerted by pollutants in the short-term polluted soil SS2. Further studies are however needed to confirm its suitability as a bioaugmentation candidate in remediating oil polluted temperate soils.

Among the abiotic environmental factors, temperature exerts a more direct influence on microbial populations in soil (Buckeridge et al., 2013). The relative abundance of the dominant bacterial genus (Pseudomonas) in the weathered polluted soil PS however remained constant through-out the freezing phase. This buffering potential observed in PS may be attributed to the ability of the dominant bacterial genus to adapt to the presence of hydrocarbon contaminants over extended period, hence they were very stable and not affected by perturbations likely to arise from the freezing phase. Ramadass et al. (2015) reported a similar trend in their microcosm study of the microbial community in weathered hydrocarbon contaminated arid soils. In this study, we also found that bacterial populations related to sulphur cycling (Sulfuritalea and Sulfuricurvum) occurred only in the weathered polluted soil PS. This was a major difference among the four soils in our study as the sulphur oxidizing genera were absent in CS and the short-term polluted soils SS1 and SS2. Generally, sulfur oxidation processes occur wherever reduced inorganic sulphur compounds are available (Meyer and Kuever, 2007). This suggests that sulphur mineralization was higher in PS compared to the clean soil and short-term polluted soils.

At the phylum level, the members of Proteobacteria were dominant in all the soil samples, accounting for more than $45 \%$ of bacterial phyla in both clean and polluted samples (Figs. A3-A6 in the Appendix). After repeated freezing processes, SS2 had the 
highest relative abundance of Proteobacteria (91.79\%) among the soils in the study. We found that the average abundance of Proteobacteria increased in SS2 during the freezing phase when compared to the Pre-incubation phase whereas it remained constant in PS. The results correspond roughly with previous reports. Labbe et al. (2007) suggested that cold-adapted bacteria belonging to Proteobacteria phylum can rapidly adapt to low sub-zero temperatures and retain metabolic activity for growth and survival. From our results, it was evident that repeated freezing did not influence the abundance of the dominant bacterial phyla present in PS. This means that the bacterial community composition in PS may have attained a form of equilibrium and stability prior to this phase.

During the transition phase $\left(\mathrm{T}-20^{\circ} \mathrm{C}\right)$, temperature was kept constant at $-20{ }^{\circ} \mathrm{C}$ over a period of five days and we observed that there were some distinct changes in the relative abundance of the predominant genera in the experimental soil groups (Fig. $7 a-d)$. In the clean soil CS, Arthrobacter increased in relative abundance while the abundance of Pseudomonas and Thermomonas decreased in SS1 and SS2 respectively when compared to the freezing phase. Of the classified genera in PS, the relative abundance of Pseudomonas (9.07\%) and Lutibacter (5.85\%) were higher when compared to their respective values during both pre-incubation and freezing phase. The observed variations in the soil types suggested that apart from temperature and the nature of oil contaminants present in the soil, there may be some other factors that might affect the composition of bacterial communities in the soil.

The thawing phase $\left(\mathrm{T}-10{ }^{\circ} \mathrm{C}\right.$ to $\mathrm{T} 20^{\circ} \mathrm{C}$ ) in this study was of particular importance because it represented a projection of increasing temperature consistent with global warming indices in Asia (Lin et al., 2018). During this phase, we observed higher relative abundance in the predominant bacterial genera in all the soil groups (Figs. 811). By the end of this phase, Janthinobacterium (9.28\%), Pseudomonas (11.31\%), Thermomonas $(80.27 \%)$ and Pseudomonas $(7.09 \%)$ were the predominant genera in CS, SS1, SS2 and PS. Although this pattern of dominance was similar to what was observed during in the initial pre-incubation and freezing phases, there was a remarkable increase in their relative abundance. For instance, the relative abundance of Thermomonas by the end of thawing phase (Fig. 11c) was 2.04 and 1.50 times higher when compared to the pre-incubation (Fig. 2c) and freezing phases (Fig. 6c) respectively. The thawing phase in soil has been well interpreted. Koponen et al. (2006) earlier reported that soil freeze-thaw events can increase nutrient concentration by destroying microbes resulting in the increased activity of the surviving microbes. This phenomenon was most evident in SS2, where the relative abundance of the predominant genus Thermomonas responded most positively to the warm thawing phase. Another distinct occurrence during the thawing phase was the appearance of some new genera such as Hydrogenophaga (0.77\%), Shingomonas $(0.16 \%)$ and Tolumonas $(0.7 \%)$ in SS1, SS2 and PS respectively. Overall, our findings suggest that rising temperatures in the thawing phase favoured the growth of both predominant and rare petroleum degrading genera in the polluted soils.

Figures A7-A11 displayed the bacterial community composition at the phylum level, and we found that the thawing phase compensated for the decreases in relative abundance of the predominant phylum (Proteobacteria) in CS, SS1 and SS2 that occurred during the freezing phase. This is consistent with previous report that relative warmer temperature resulted in increased bacterial growth (Jiang et al., 2018). 
a.
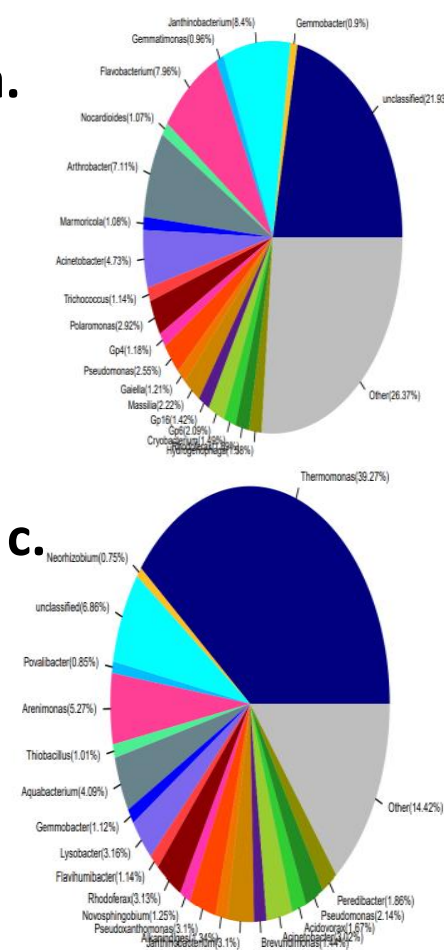

b.

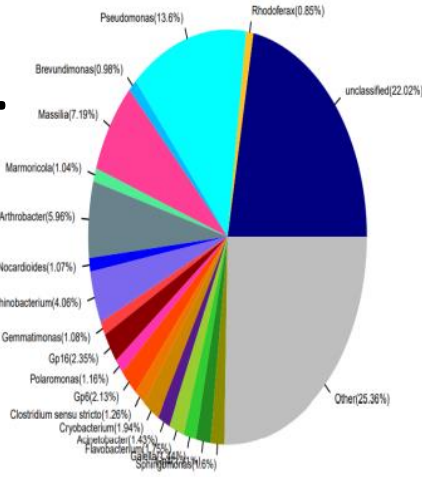

d.

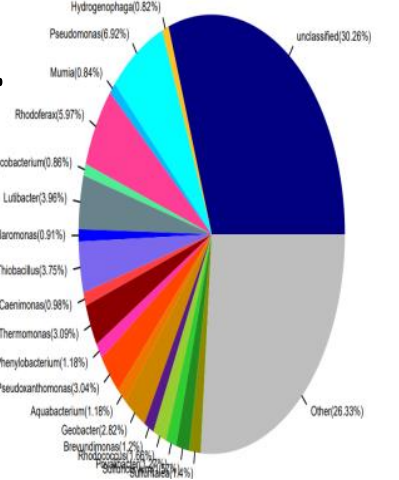

Figure 2. a-d Bacterial genus composition in (a) Clean natural soil CS (b) Diesel-oil amended soil SS1 (c) Crude-oil amended soil SS2 (d) weathered petroleum-polluted soil PS at Preincubation phase $\left(F 20^{\circ} \mathrm{C}\right)$
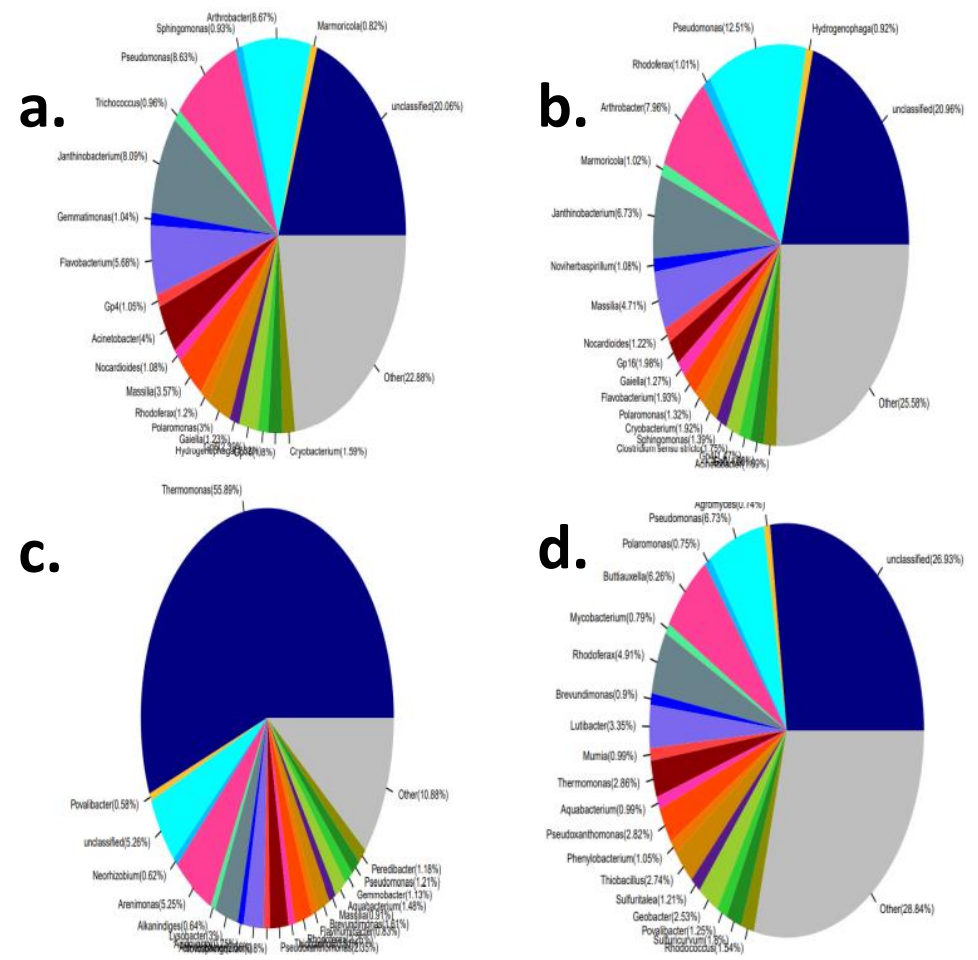

Figure 3. a-d Bacterial genus composition in (a) Clean natural soil CS (b) Diesel-oil amended soil SS1 (c) Crude-oil amended soil SS2 (d) weathered petroleum-polluted soil PS during Freezing phase $\left(F 10^{\circ} \mathrm{C}\right)$ 
a.

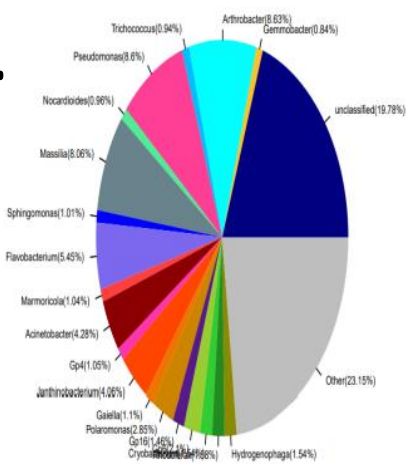

C.

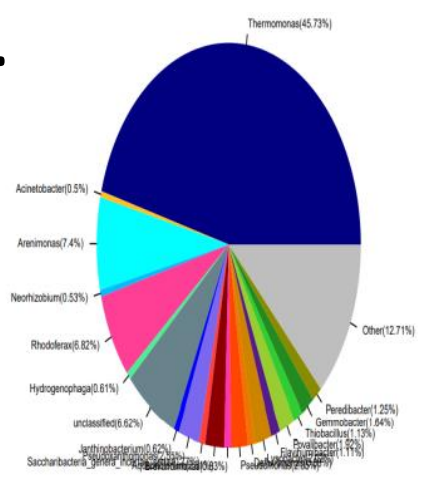

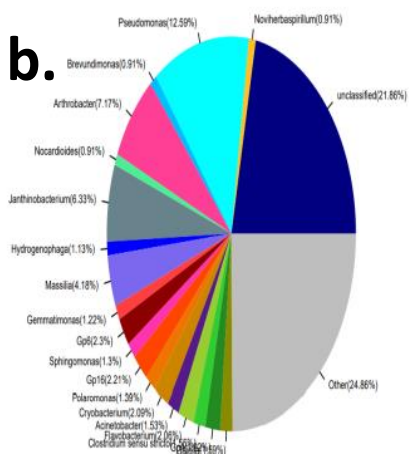

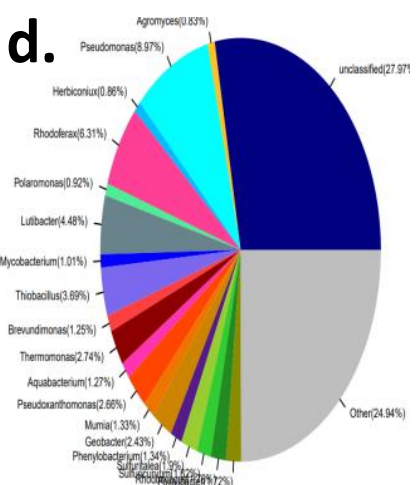

Figure 4. a-d Bacterial genus composition in (a) Clean natural soil CS (b) Diesel-oil amended soil SS1 (c) Crude-oil amended soil SS2 (d) weathered petroleum-polluted soil PS during Freezing phase $\left(\mathrm{F} 0{ }^{\circ} \mathrm{C}\right)$
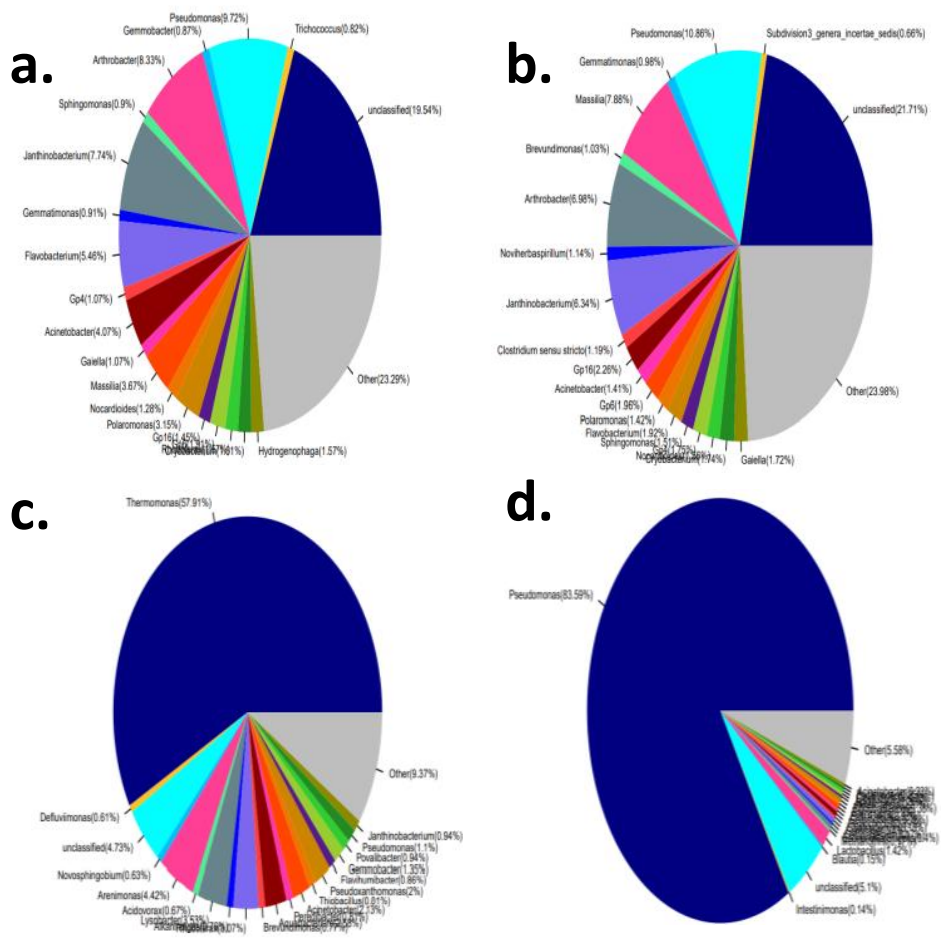

Figure 5. a-d Bacterial genus composition in (a) Clean natural soil CS (b) Diesel-oil amended soil SS1 (c) Crude-oil amended soil SS2 (d) weathered petroleum-polluted soil PS during Freezing phase $\left(F-10{ }^{\circ} \mathrm{C}\right)$ 

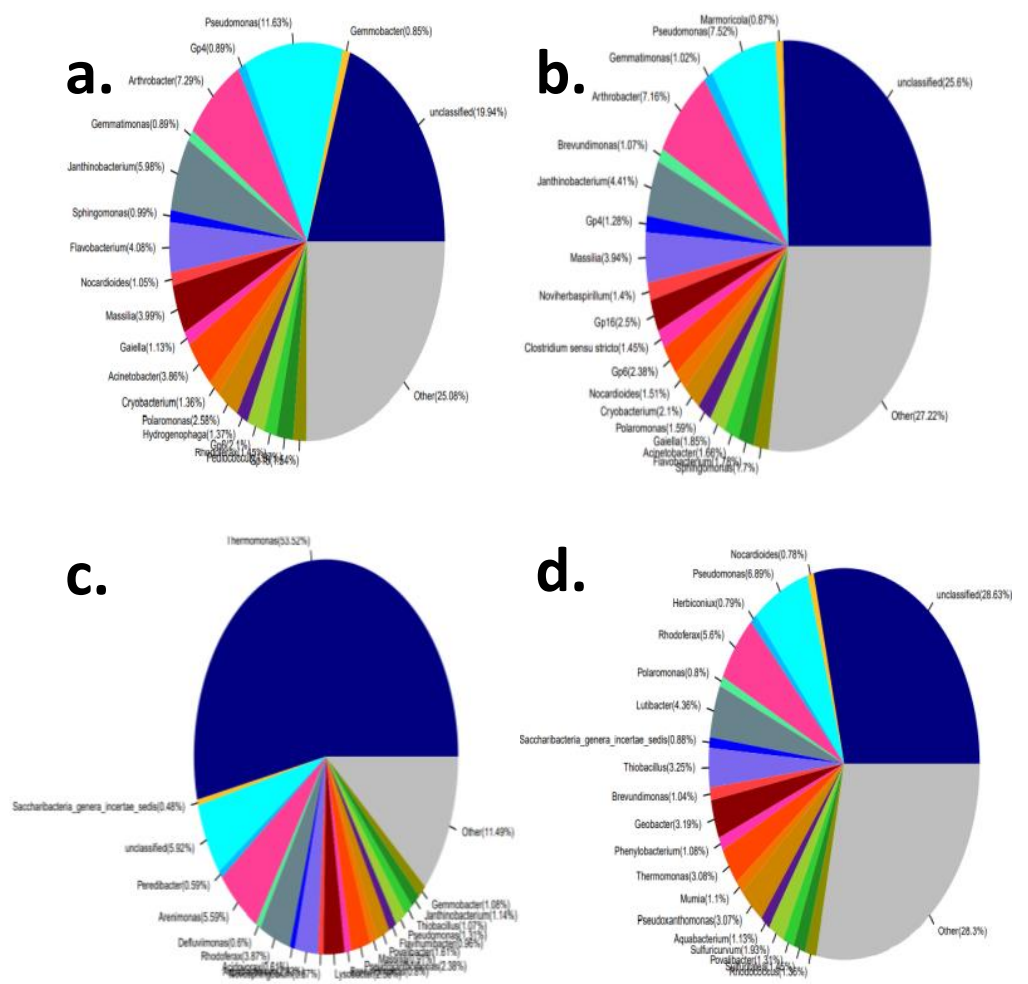

Figure 6. a-d Bacterial genus composition in (a) Clean natural soil CS (b) Diesel-oil amended soil SS1 (c) Crude-oil amended soil SS2 (d) weathered petroleum-polluted soil PS during Freezing phase $\left(F-20{ }^{\circ} \mathrm{C}\right)$
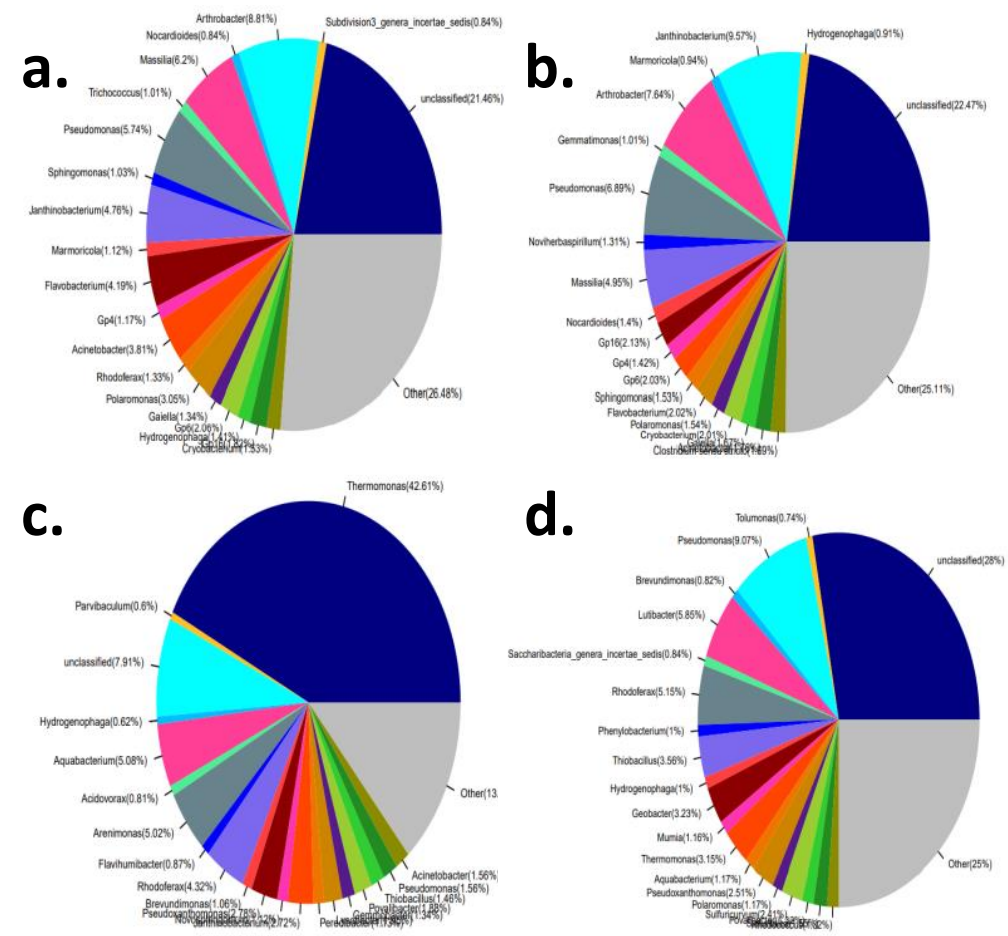

Figure 7. a-d Bacterial genus composition in (a) Clean natural soil CS (b) Diesel-oil amended soil SS1 (c) Crude-oil amended soil SS2 (d) weathered petroleum-polluted soil PS during

Transition phase $\left(T-20^{\circ} \mathrm{C}\right)$ 

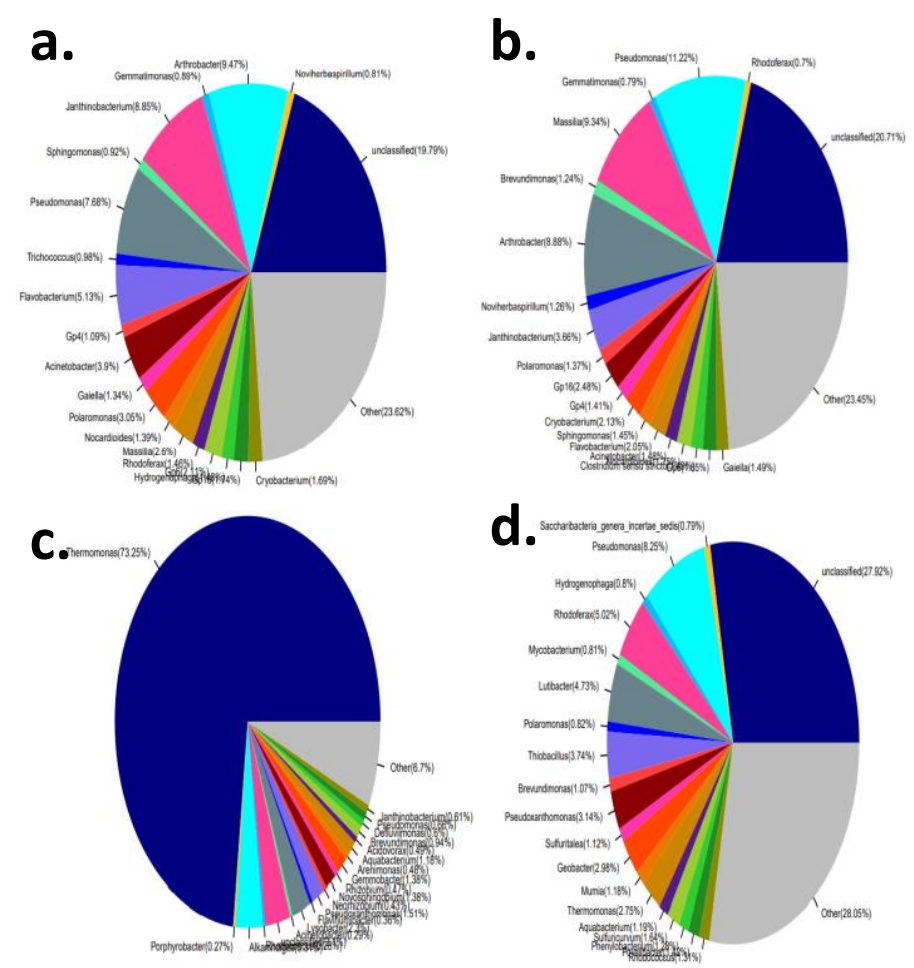

Figure 8 a-d. Bacterial genus composition in (a) Clean natural soil CS (b) Diesel-oil amended soil SS1 (c) Crude-oil amended soil SS2 (d) weathered petroleum-polluted soil PS during Thawing phase $\left(T-10{ }^{\circ} \mathrm{C}\right)$
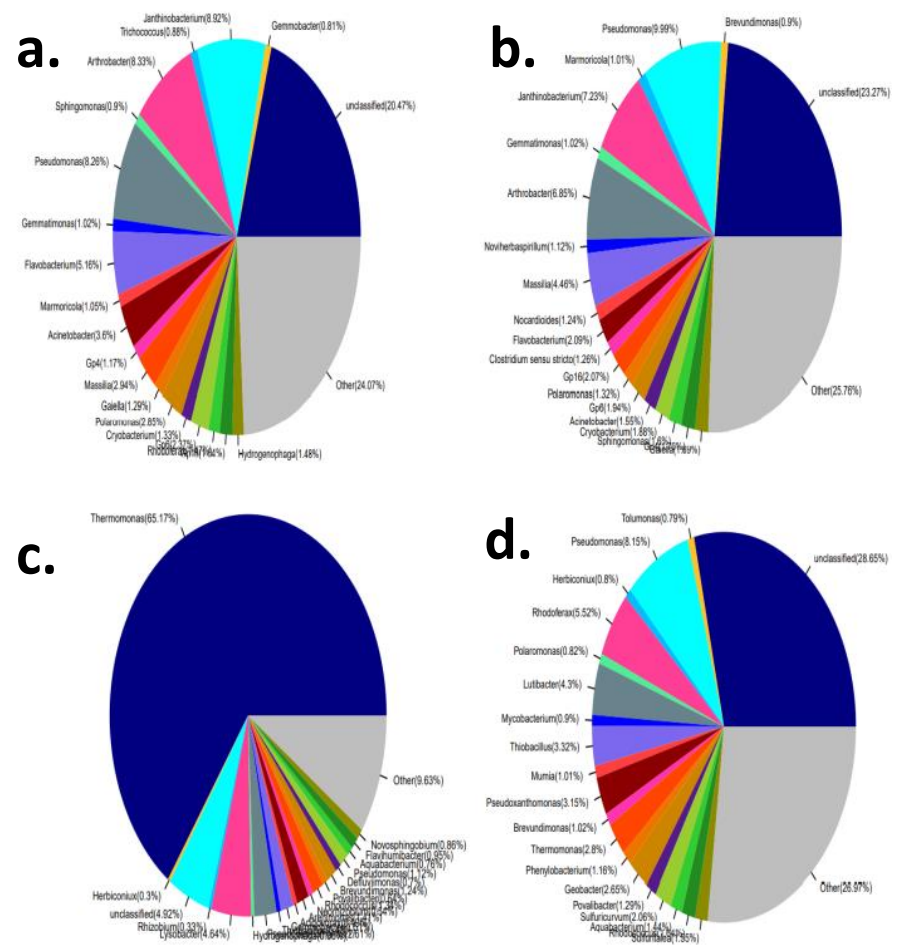

Figure 9 a-d. Bacterial genus composition in (a) Clean natural soil CS (b) Diesel-oil amended soil SS1 (c) Crude-oil amended soil SS2 (d) weathered petroleum-polluted soil PS during

Thawing phase $\left(\mathrm{T} 0{ }^{\circ} \mathrm{C}\right)$ 

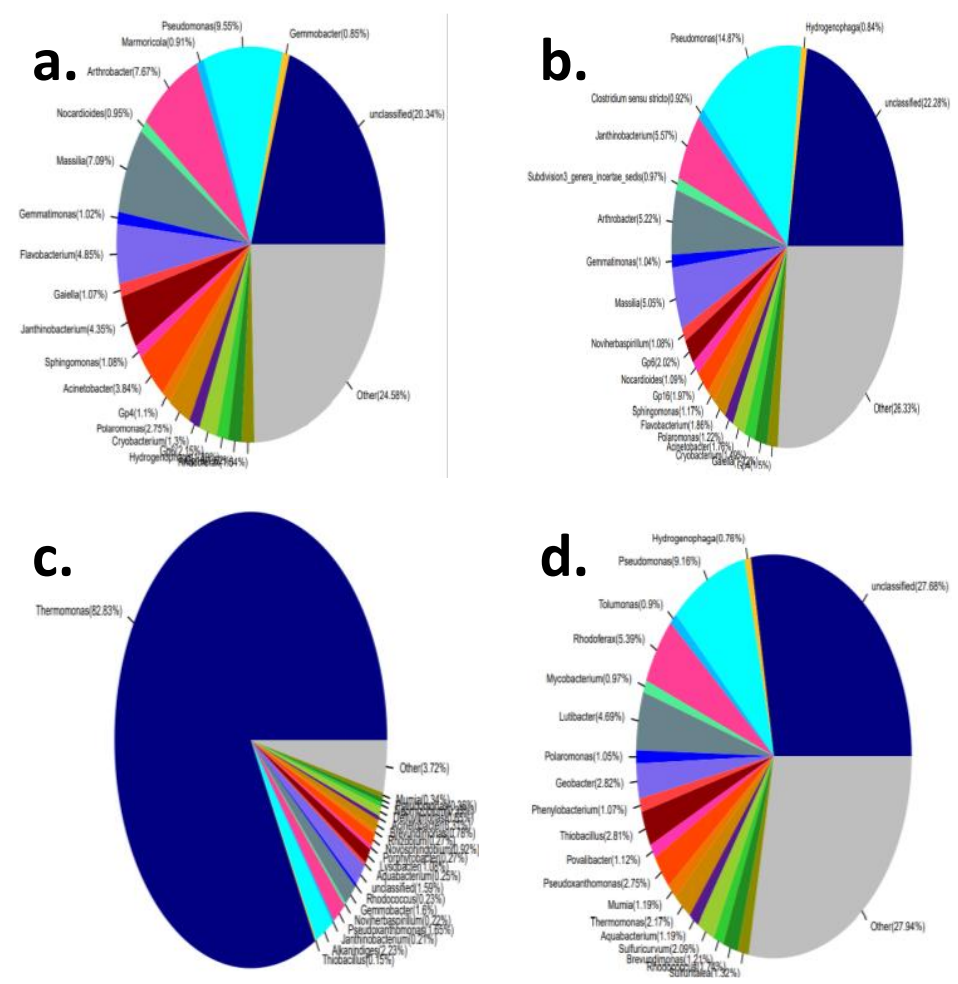

Figure 10. a-d Bacterial genus composition in (a) Clean natural soil CS (b) Diesel-oil amended soil SS1 (c) Crude-oil amended soil SS2 (d) weathered petroleum-polluted soil PS during Thawing phase $\left(T 10^{\circ} \mathrm{C}\right)$
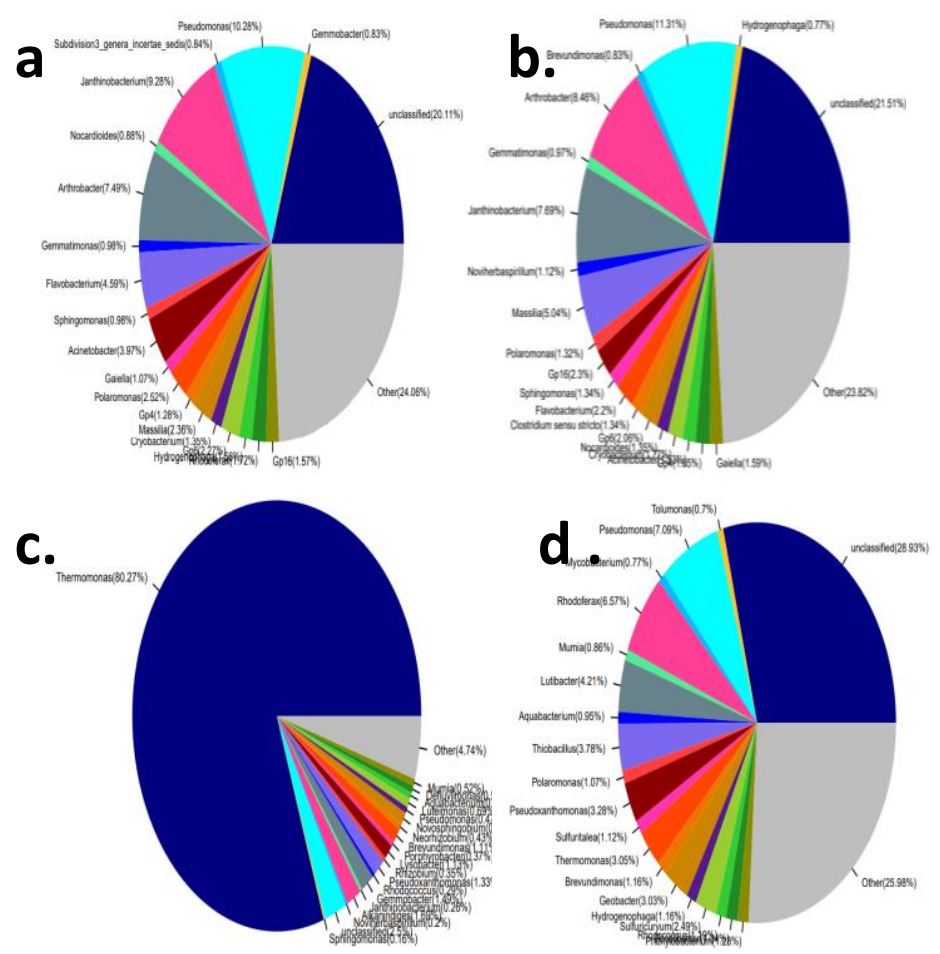

Figure 11. a-d Bacterial genus composition in (a) Clean natural soil CS (b) Diesel-oil amended soil SS1 (c) Crude-oil amended soil SS2 (d) weathered petroleum-polluted soil PS during Thawing phase $\left(T 20^{\circ} \mathrm{C}\right)$ 


\section{Bacterial community alpha diversity and presence of unique bacterial species}

The results of the OTU richness and diversity analyses at the beginning of the study (F $20^{\circ} \mathrm{C}$ ) showed that the richness index (ACE and Chao 1) and the uniformity index (Shannon) varied among the soil samples (Table 2). It can be seen that the alpha diversity indices of CS was the highest while the Simpson index of SS2 was the highest. In all the samples, the order was CS > PS > SS1 > SS2 for ACE index and CS > SS1 > PS > SS2 for Shannon index. Therefore, compared to the polluted soils the bacterial diversity and richness in the clean soil was higher. Further comparison of the weathered petroleum contaminated soil PS to the short-term polluted soils revealed that the bacterial community diversity was reduced in SS1 and SS2 and this decrease was more evident in the SS2. Sutton et al. (2013) have previously reported that the presence of oil contamination significantly influences bacterial community structure and diversity, regardless of the soil matrix type, and suggested that clean samples had higher diversity than contaminated soil. From our results, we infer that the duration of oil contamination is a crucial factor that could affect bacterial community diversity and richness. The higher diversity seen in the weathered polluted soil may be attributed to a form of community adaptation to long term oil exposure. Earlier investigations conducted on long-term petroleum polluted soils also reported a trend of higher diversity when compared to newly contaminated soils (Bourceret et al., 2016; Jeanbille et al., 2016). Venn diagram (Fig. A12) showed the occurrence of unique bacterial species in the soil samples; 76, 85, 3 and 109 unique species were identified in the clean CS, diesel amended SS1, crude oil amended SS2, and weathered petroleum polluted PS soil respectively during the pre-incubation phase. This result indicated that the introduction of petroleum products in the soil had immediate impacts on the unique bacterial species with the number of unique species increasing and decreasing notably in the short-term polluted soils SS1 and SS2 respectively. In particular, sequences related to Thermomonas were found to constitute $39.27 \%$ of total sequences in the shortterm polluted soil SS1 suggesting that the selective enrichment of the genus Themomonas may have led to the suppression of other unique bacterial species in SS2. Hence, the number of unique bacterial species in the soil samples varied as a result of contamination type with diesel and crude-oil amended soils showing distinct bacterial responses. Borowik and Wyszkowska (2018) also reported that petroleum products induced noticeable changes at the species level in polluted soils. Our results are consistent with their findings.

The alpha diversity indices of the clean and polluted soils during the freezing phase are presented in Table 3. The ACE index identified differences between the clean soil and the polluted soils indicating that PS had more variety of organisms than CS, SS1 and SS2 after repeated freezing. This suggests that the bacterial population in the weathered polluted soil PS are most likely cold-adapted microorganisms which are able to tolerate and survive subzero freezing temperatures. By the end of the freezing phase, the order in the soil was $\mathrm{PS}>\mathrm{CS}>\mathrm{SS} 1>\mathrm{SS} 2$ for $\mathrm{ACE}$ index and $\mathrm{SS} 2>\mathrm{CS}=\mathrm{PS}>\mathrm{SS} 1$ for Simpson index. Interestingly, the richness remained constant in both CS and PS during the freezing phase while community decreased and increased in SS1 and SS2 respectively. In this study, we inferred that the observed changes in richness in the newly contaminated soils SS1 and SS2 were more likely as a result of their recent pollution status rather than the exposure to freezing temperature amplitude since the community richness in the clean (control) soil remained constant. The environmental disturbance of oil contamination is one of the most significant anthropogenic activities that affect soil microbial communities (Liu et al., 2017). 
Table 2. Bacterial diversity indices in the clean and polluted soils during the pre-incubation phase of the study

\begin{tabular}{|c|c|c|c|c|}
\hline \multicolumn{5}{|c|}{ Pre-incubation phase $\left(20^{\circ} \mathrm{C}\right)$} \\
\hline Soil type & CS & SS1 & SS2 & PS \\
\hline \multicolumn{5}{|l|}{ Sequencing analysis } \\
\hline Sequence number & 46700 & 50682 & 33068 & 30015 \\
\hline OTUs number & 4772 & 4413 & 1611 & 3118 \\
\hline \multicolumn{5}{|l|}{ Diversity indices } \\
\hline \multicolumn{5}{|l|}{ OTU diversity } \\
\hline Ace index & 9288.75 & 6492.4 & 5231.8 & 8832.5 \\
\hline Chaol index & 7268.28 & 6144.1 & 3585.2 & 5814.3 \\
\hline \multicolumn{5}{|l|}{ OTU richness } \\
\hline Shannon index & 6.09 & 6.03 & 3.67 & 5.56 \\
\hline Simpson index & 0.02 & 0.02 & 0.16 & 0.02 \\
\hline Coverage & 0.95 & 0.97 & 0.97 & 0.94 \\
\hline
\end{tabular}

CS: Clean soil, SS1: Short-term diesel-oil polluted soil, SS2: Short-term crude-oil polluted soil, PS: Weathered petroleum polluted soil

Table 3. Bacterial diversity indices in the clean and polluted soils during the freezing phase $\left(10\right.$ to $\left.-20^{\circ} \mathrm{C}\right)$ of the study

\begin{tabular}{|c|c|c|c|c|c|c|c|c|c|c|c|c|c|c|c|c|}
\hline SOIL TYPE & \multicolumn{4}{|c|}{ CS } & \multicolumn{4}{|c|}{ SS1 } & \multicolumn{4}{|c|}{ SS2 } & \multicolumn{4}{|c|}{ PS } \\
\hline $\begin{array}{l}\text { Temp }\left({ }^{\circ} \mathrm{C}\right) \\
\text { Sequencing analysis }\end{array}$ & 10 & 0 & -10 & -20 & 10 & 0 & -10 & -20 & 10 & 0 & -10 & -20 & 10 & 0 & -10 & -20 \\
\hline Sequence number & 40660 & 48121 & 44967 & 49853 & 40853 & 49482 & 52643 & 55260 & 34280 & 32302 & 29937 & 33077 & 33299 & 20717 & 44020 & 47781 \\
\hline OTUs number & 4282 & 4715 & 4483 & 4724 & 4079 & 4522 & 4396 & 4709 & 1493 & 1692 & 1377 & 1653 & 2739 & 2631 & 441 & 3620 \\
\hline $\begin{array}{l}\text { Diversity indices } \\
\text { OTU Richness }\end{array}$ & & & & & & & & & & & & & & & & \\
\hline Ace index & 9538 & 10774 & 9906 & 7745 & 78921 & 8318 & 8333 & $6713, .6$ & 5177 & 5713 & 4982 & 5637 & 7654 & 8090 & 451.3 & 9679 \\
\hline $\begin{array}{l}\text { Chaol index } \\
\text { OTU Diversity }\end{array}$ & 7097 & 7916 & 7470 & 7338 & 6196 & 6699 & 6581 & 6476 & 3072 & 3465 & 2999 & 3548 & 5250 & 5189 & 463.6 & 6672 \\
\hline Shannon index & 5.87 & 5.87 & 5.91 & 5.98 & 5.91 & 6.04 & 5.96 & 6.3 & 2.93 & 3.39 & 2.86 & 3.13 & 5.47 & 5.61 & 1.93 & 5.51 \\
\hline Simpson index & 0.02 & 0.02 & 0.02 & 0.02 & 0.02 & 0.02 & 0.02 & 0.01 & 0.31 & 0.21 & 0.33 & 0.28 & 0.02 & 0.02 & 0.36 & 0.02 \\
\hline Coverage & 0.95 & 0.95 & 0.95 & 0.96 & 0.96 & 0.96 & 0.96 & 0.97 & 0.97 & 0.97 & 0.97 & 0.97 & 0.97 & 0.93 & 0.99 & 0.96 \\
\hline
\end{tabular}

CS: Clean soil, SS1: Short-term diesel-oil polluted soil, SS2: Short-term crude-oil polluted soil, PS: Weathered petroleum polluted soil

The analysis of diversity indices during transition phase showed that CS had the highest bacterial diversity and richness when compared to the polluted soils (Table 4). The transition phase was characterized by a marked increase in the diversity in all the soil groups compared to the freezing phase thereby suggesting that the bacterial populations in the soil eventually develop coping mechanisms for extended period of lower temperature. Chattopadhyay (2002) reported that certain soil bacteria contain cryoprotective compounds such as mannitol, sorbitol, betaine etc. These low molecular weight compounds suppress the aggregation of cellular proteins during stress conditions. Other cold adapted bacterial populations have been reported to prevent cell death by using endogenous biopolymers such as extracellular polymeric substances (EPS, primarily polysaccharides). The EPS forms a capsule around the cell and prevents cell death from osmotic stress, and mechanical ice damage (Junge et al., 2006). The 
presence of bacterial cryoprotectants may be responsible for the increased diversity in all the soil groups. However, further studies may be required to confirm the nature and mechanism of cryoprotection in the oil polluted temperate soils.

Table 4. Bacterial diversity indices in the clean and polluted soils during the transition phase of the study

\begin{tabular}{c|c|c|c|c}
\hline & \multicolumn{4}{|c}{ Transition phase $\left(-\mathbf{2 0}{ }^{\circ} \mathbf{C}\right)$} \\
\hline Soil type & CS & SS1 & SS2 & PS \\
\hline Sequencing analysis & & & & \\
\hline Sequence number & 44899 & 59493 & 35225 & 35520 \\
\hline OTUs number & 4623 & 5039 & 1800 & 3143 \\
\hline Diversity indices & & & & \\
\hline OTU richness & & & & \\
\hline Ace index & 10203 & 10014 & 5939.8 & 8905 \\
\hline Chao1 index & 7715.6 & 7893.8 & 3785.1 & 6078.2 \\
\hline OTU diversity & & & & \\
\hline Shannon index & 6.09 & 5.98 & 3.61 & 5.51 \\
\hline Simpson index & 0.02 & 0.02 & 0.18 & 0.02 \\
\hline Coverage & 0.95 & 0.96 & 0.97 & 0.95 \\
\hline
\end{tabular}

CS: Clean soil, SS1: Short-term diesel-oil polluted soil, SS2: Short-term crude-oil polluted soil, PS:

Weathered petroleum polluted soil

The results of the OTU richness and diversity analyses during the thawing phase showed that bacterial diversity varied among the soil samples (Table 5). The order was $\mathrm{PS}>\mathrm{SS} 1>\mathrm{CS}>\mathrm{SS} 2$ for ACE index and SS1 > CS > PS > SS1 for Shannon index. The diversity was higher in the polluted soils compared to the clean soil. In a previous study by Peng and colleagues (2015), they reported that oil-polluted soils supported more diverse bacterial community compared to the clean soil. Our findings during the thawing phase agree with their report. Although their study was for a single temperature regime, the present study highlights the changes in bacterial diversity that occurs when polluted soils are continuously subjected to warmer temperature regimes after a period of freezing. Similarly, the bacterial community richness changed after the thawing phase. A higher bacterial richness was observed in the crude oil contaminated soils when compared to the clean soil.

\section{Beta diversity of bacterial communities}

The principal component analysis (PCA) based on UniFrac distances (Fig. 12) revealed that the bacterial communities in the four soil samples clustered separately based on soil contamination levels. However, the bacterial communities of CS and SS1 were grouped in a cluster. The result indicated that the bacterial communities in the clean soil and diesel polluted soil were more similar to each other than the bacterial communities in the crude-oil polluted soils SS1 and PS during freezing and thawing phases. When the bacterial communities in the clean and polluted soils were compared at the phylum level, the communities in the soil groups were clustered in different axes (Fig. 12). Regardless of the temperature regime, samples from each of the soil groups clustered in the same axis. The result indicated that the dissimilarity in bacterial 
communities in the soil groups were more as a function of their contamination level rather than the freeze-thaw regime. Borowik et al. (2019) reported that the presence of petroleum product in a soil creates a new microenvironment which may greatly alter its biological properties. Our results are in consonance with their finding.

Table 5. Bacterial diversity indices in the clean and polluted soils during the thawing phase of the study

\begin{tabular}{|c|c|c|c|c|c|c|c|c|c|c|c|c|c|c|c|c|}
\hline \multicolumn{17}{|c|}{ THAWING PHASE (-10 to $\left.20^{\circ} \mathrm{C}\right)$} \\
\hline SOIL TYPE & \multicolumn{4}{|c|}{$\mathbf{C S}$} & \multicolumn{4}{|c|}{ SS1 } & \multicolumn{4}{|c|}{ SS2 } & \multicolumn{4}{|c|}{ PS } \\
\hline $\operatorname{Temp}\left({ }^{\circ} \mathrm{C}\right)$ & -10 & 0 & 10 & 20 & -10 & 0 & 10 & 20 & -10 & 0 & 10 & 20 & -10 & 0 & 10 & 20 \\
\hline Sequence numbe & 45310 & 49162 & 45362 & 53116 & 49803 & 42728 & 41318 & 47468 & 36278 & 36982 & 35132 & 46393 & 27844 & 34179 & 38974 & 37844 \\
\hline OTUs num & 4623 & 4895 & 4530 & 4787 & 4499 & 4229 & 3833 & 4485 & 1066 & 1521 & 801 & 1031 & 2596 & 3224 & 3330 & 3464 \\
\hline \multicolumn{17}{|l|}{ OTU Diversity } \\
\hline ACE index & 10249 & 10343 & 9137 & 7446 & 8992 & 8602 & 5565 & 9057 & 4432 & 5485 & 3349 & 3521 & 7325 & 8506 & 9257 & 10134 \\
\hline Chao1 index & 7641 & 7807 & 7087 & 6977 & 7067 & 6586 & 5334 & 6992 & 2729 & 3401 & 1796 & 2328 & 5001 & 5895 & 6294 & 6738 \\
\hline OTU Richness & & & & & & & & & & & & & & & & \\
\hline Shannon index & 5.88 & 5.97 & 5.97 & 5.89 & 5.89 & 6.05 & 6 & 5.91 & 1.93 & 2.48 & 1.32 & 1.56 & 5.49 & 5.56 & 5.55 & 5.53 \\
\hline Simpson index & 0.02 & 0.02 & 0.02 & 0.02 & 0.02 & 0.02 & 0.02 & 0.02 & 0.52 & 0.42 & 0.68 & 0.62 & 0.02 & 0.02 & 0.02 & 0.02 \\
\hline Coverage & 0.95 & 0.95 & 0.95 & 0.96 & 0.96 & 0.95 & 0.96 & 0.96 & 0.98 & 0.98 & 0.99 & 0.99 & 0.95 & 0.95 & 0.95 & 0.95 \\
\hline
\end{tabular}

CS: Clean soil, SS1: Short-term diesel-oil polluted soil, SS2: Short-term crude-oil polluted soil, PS: Weathered petroleum polluted soil

PCA2(3\%) VS PCA3(0\%)

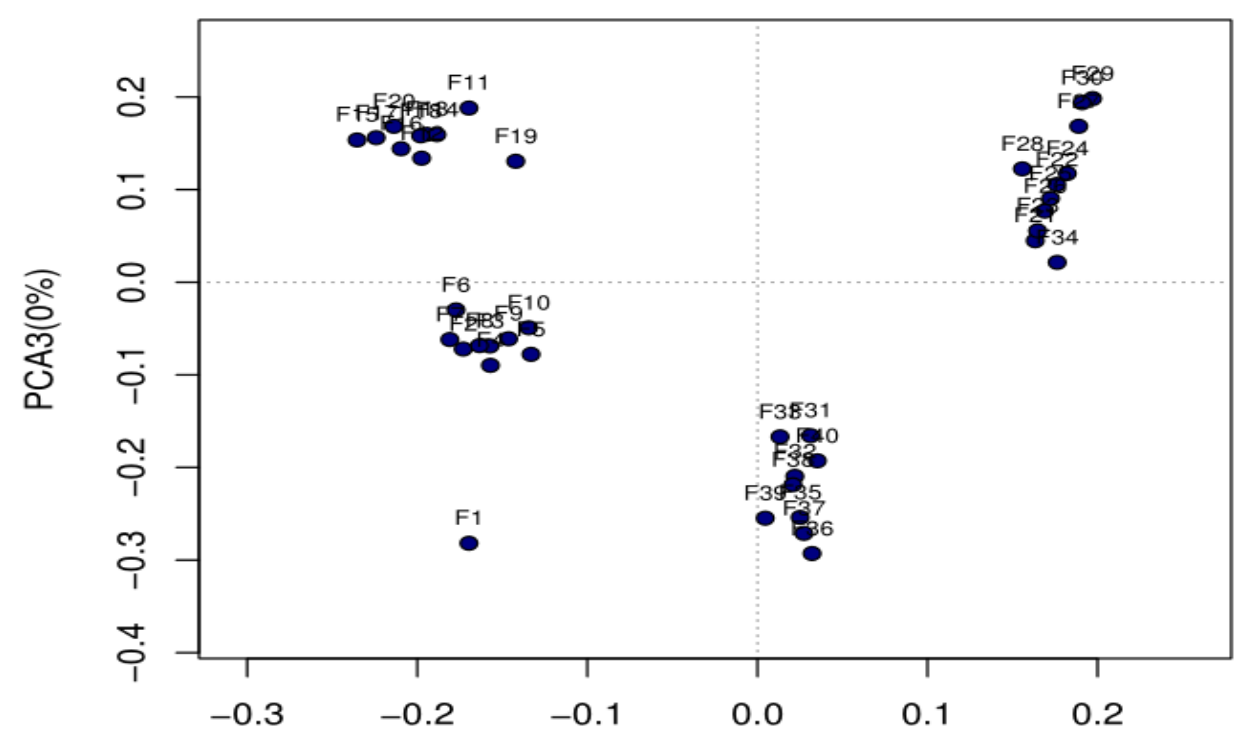

Figure 12. Weighted UniFrac principal component analysis (PCA) at the phylum level based on the 16S rDNA gene sequence in the soil samples. F1: CS, F11: SS1, F21: SS2, F31: PS (F $20{ }^{\circ} \mathrm{C}$, Pre-incubation phase). F2: CS, F12: SS1, F22: SS2, F32: PS (F $10{ }^{\circ} \mathrm{C}$, Freezing phase). F3: CS, F13: SS1, F23: SS2, F33: PS (F $0^{\circ} \mathrm{C}$, Freezing phase). F4: CS, F14: SS1, F24: SS2, F34: PS (F-10 ${ }^{\circ} \mathrm{C}$, Freezing phase). F5: CS, F15: SS1, F25: SS2, F35: PS (F-20 ${ }^{\circ} \mathrm{C}$, Freezing phase). F6: CS, F16: SS1, F26: SS2, F36: PS (T-10 ${ }^{\circ} \mathrm{C}$, Transition phase). F7: CS, F17: SS1, F27: SS2, F37: PS (T0 ${ }^{\circ} \mathrm{C}$, Thawing phase). F8: CS, F18: SS1, F28: SS2, F38: PS $\left(T 0^{\circ} \mathrm{C}\right.$, Thawing phase). F9: CS, F19: SS1, F29: SS2, F39: PS (T0 ${ }^{\circ} \mathrm{C}$, Thawing phase). F10: CS, F20: SS1, F30: SS2, F40: PS (TO ${ }^{\circ} \mathrm{C}$, Thawing phase) 


\section{Functional prediction of bacterial communities}

For pathways prediction (Figs. 13 and 14), the clean and polluted soil samples were aggregated into two major clusters.

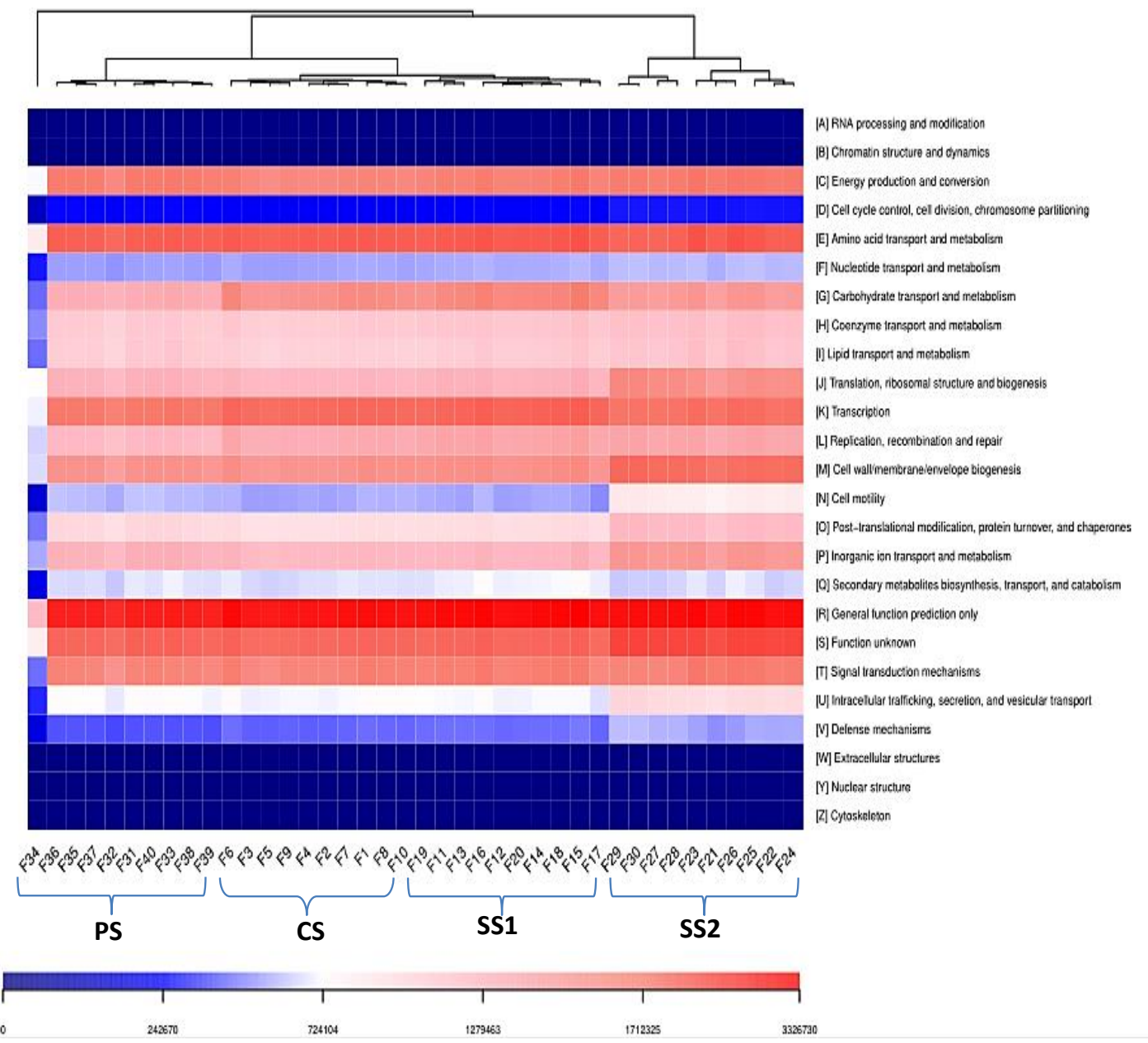

Figure 13. Heat map showing relative abundances of clusters of orthologous group $(C O G)$ categories predicted by PICRUSt. The relationship among specimens is determined by the complete clustering method with Bray-Curtis distance. In the heat map, the red and blue colors indicate high and low relative abundance, respectively

Bacteria indicated that the pathways of amino acid and carbohydrate metabolism, cellular processes and signalling, energy production and conversion, glycan synthesis and metabolism, xenobiotic biodegradation and translation mechanisms were the functions most abundant in all samples during the freeze-thaw experiments. There was no clear cluster based on the freezing and thawing phases in the samples except SS2. This indicated that the predicted function of bacteria population was more related to their contamination level than freeze-thaw temperature regimes. Previous study by Auti et al. (2016) also identified xenobiotic biosynthesis, carbohydrate metabolism and glycan biosynthesis terms in their petroleum polluted soil samples. The results were indicative of the predictive microbiomes of polluted soils SS1, SS2 and PS having the metabolic capacity associated with the degradation of xenobiotic compounds in the company of carbohydrate metabolism. 


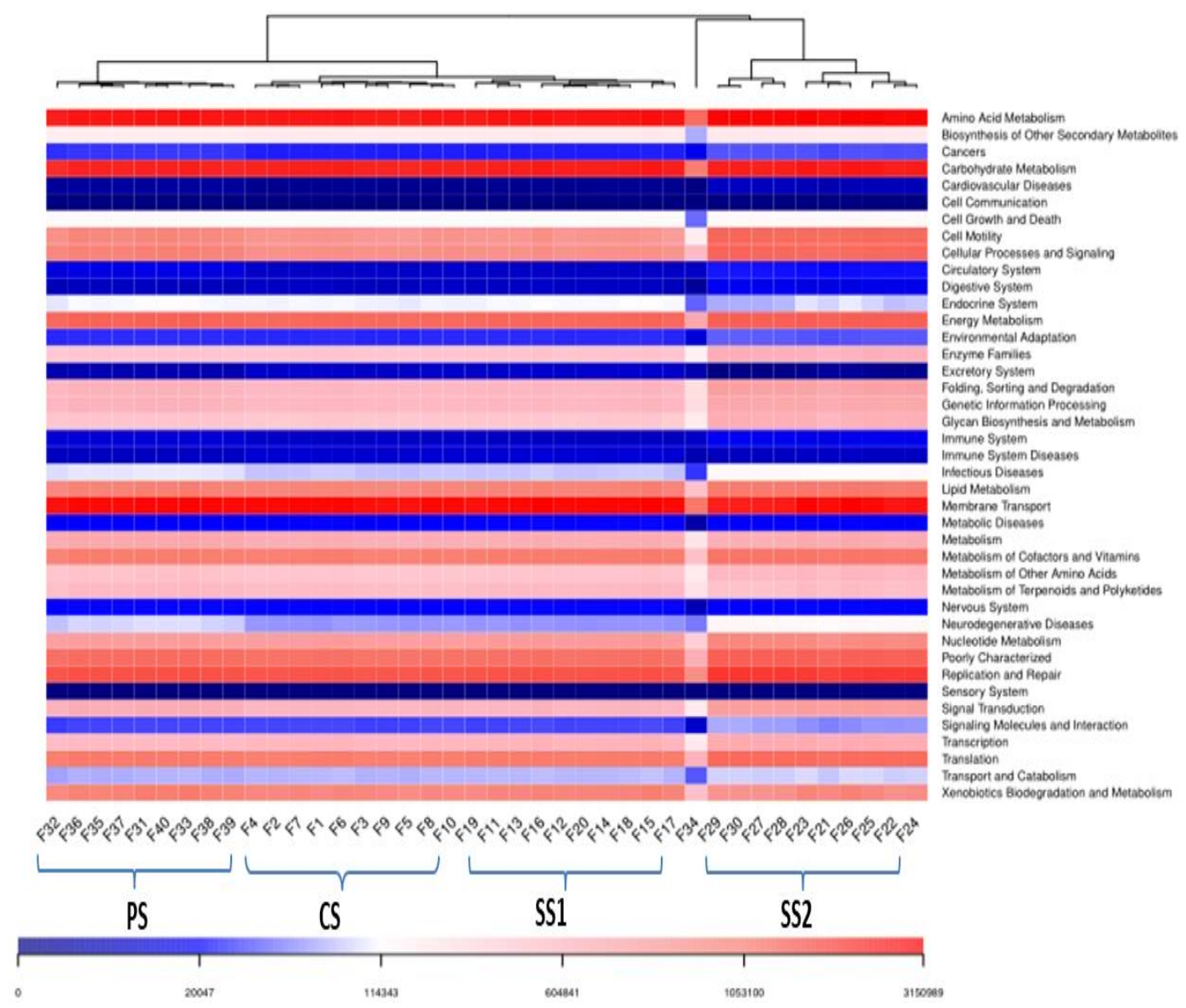

Figure 14. Clustered heatmap of KEGG pathway enrichment analysis. F1: CS, F11: SS1, F21: SS2, F31: PS (F $20{ }^{\circ} \mathrm{C}$, Pre-incubation phase). F2: CS, F12: SS1, F22: SS2, F32: PS ( F $10{ }^{\circ} \mathrm{C}$, Freezing phase). F3: CS, F13: SS1, F23: SS2, F33: PS (F $0{ }^{\circ} \mathrm{C}$, Freezing phase). F4: CS, F14: SS1, F24: SS2, F34: PS (F-10 ${ }^{\circ} \mathrm{C}$, Freezing phase). F5: CS, F15: SS1, F25: SS2, F35: PS (F $20{ }^{\circ} \mathrm{C}$, Freezing phase). F6: CS, F16: SS1, F26: SS2, F36: PS (T-10 ${ }^{\circ} \mathrm{C}$, Transition phase). F7: CS, F17: SS1, F27: SS2, F37: PS (T $0^{\circ} \mathrm{C}$, Thawing phase). F8: CS, F18: SS1, F28: SS2, F38: PS (T $0{ }^{\circ} \mathrm{C}$, Thawing phase). F9: CS, F19: SS1, F29: SS2, F39: PS (T $0^{\circ} \mathrm{C}$, Thawing phase). F10: CS, F20: SS1, F30: SS2, F40: PS (T0 ${ }^{\circ} \mathrm{C}$, Thawing phase)

\section{Conclusion}

This study provides important information on the impact of freeze-thaw events on the distribution characteristics of the bacterial communities in clean and petroleum polluted temperate soils with varying duration of oil exposure. The bacterial community compositions in the short-term polluted soils were more responsive to the freezing and thawing events while community richness remained relatively constant in the clean and weathered polluted soils during the freezing and thawing phases of the study. The important and interesting phenomenon found in the study was that the bacterial community composition in the short-term and weathered polluted temperate soils were more responsive to the presence of oil contaminants than the freezing and thawing events. Overall, our results provide insight on how the compositional structure of soil microbial communities in soils are modified as a result of oil contamination and freezethaw events. Nonetheless, the results reported in the study must be interpreted with 
caution considering the small sample size involved. Future work may focus on the studying the comparative influence of freeze-thaw events on polluted soils from different cold regions and also the biodegradation potentials of isolated microorganisms from short-term polluted soils and their application in on-field remediation approaches for cold sites.

Acknowledgements. This work was supported by the National Water Pollution Control and Treatment Science and Technology Major Project (No. 2018ZX07109-003) of China. The first author is grateful to the Petroleum Technology Development Fund for the doctoral scholarship award.

\section{REFERENCES}

[1] Aislabie, J. M., Balks, M. R., Foght, J. M., Waterhouse, E. J. (2004): Hydrocarbon spills on Antarctic soils: Effects and management. - Environmental Science and Technology 38(5): 1265-1274.

[2] Baek, K. H., Yoon, B. D., Kim, B. H., Cho, D. H., Lee, I. S., Oh, H. M., Kim, H. S. (2007): Monitoring of microbial diversity and activity during bioremediation of crude oilcontaminated soil with different treatments. - Journal of Microbiology and Biotechnology 17: 67-73.

[3] Bell, T. W., Menzer, O., Troyo-Diéquez, E., Oechel, W. C. (2012): Carbon dioxide exchange over multiple temporal scales in an arid shrub ecosystem near La Paz, Baja California Sur, Mexico. - Global Change Biology 18(8): 2570-2582.

[4] Borowik, A., Wyszkowska, J., Kucharski, M., Kucharski, J. (2019): Implications of soil pollution with diesel oil and BP petroleum with ACTIVE technology for soil health. International Journal of Environmental Research and Public Health 16(14): 2474-2485.

[5] Børresen, M. H., Barnes, D. L., Rike, A. G. (2007): Repeated freeze-thaw cycles and their effects on mineralization of hexadecane and phenanthrene in cold climate soils. - Cold Region Science and Technology 49(3): 215-25.

[6] Buckeridge, K. M., Banerjee, S., Siciliano, S. D., Grogan, P. (2013): The seasonal pattern of soil microbial community structure in mesic low arctic tundra. - Soil Biology and Biochemistry 65: 338-347.

[7] Caporaso, J., Kuczynsk, J., Stombaugh, J., Bittinger, K., Bushman, F. D., Costello, E. K., et al. (2010): QIIME allows analysis of high-throughput community sequencing data. Nature Methods 7(5): 335-336.

[8] Christensen, J. H., Hewitson, B., Busuioc, A., Chen, A., Gao, X., Held, I., et al. (2007): Regional Climate Projections. - In: Solomon, S., Qin, D., Manning, M., Chen, Z., Marquis, M., Averyt, K. B. (eds.) Climate Change 2007: The Physical Science Basis Contribution of Working Group I to the Fourth Assessment Report of the Intergovernmental Panel. Cambridge University Press, Cambridge, UK.

[9] Cisneros-de la Cueva, S., Martinez-Prado, M., Lopez-Miranda, J., Rojas-Contreras, J., Medrano-Roldan, H. (2016): Aerobic degradation of diesel by a pure culture of Aspergillus terreus KP862582. - Rev Mex Ing Quim. 15(2): 347-60.

[10] Edgar, R. C., Haas, B. J., Clemente, J. C., Quince, C., Knight, R. (2011): UCHIME improves sensitivity and speed of chimera detection. - Bioinformatics. 27(16): 2194-200.

[11] Gavazov, K., Ingrisch, J., Hasibeder, R., Mills, R. T. E., Buttler, A., Gleixner, G., Bahn, M. (2017): Winter ecology of a subalpine grassland: effects of snow removal on soil respiration, microbial structure and function. - Science of the Total Environment 590: 316-324.

[12] Guo, W. L., Hong-Bo, S., Jing-Jin, M., Ying-Juan, Z., Ji, W., Wen-Jun, S., Zi-Yin, Z. (2013): Basic features of climate change in North China during 1961-2010. - Advances in Climate Change Research, 4(2): 73-83. 
[13] Guoqing, L., Huadong, G., Xinwu, L., Lu, Z. (2014): Research on the temporal-spatial changes of near-surface soil freeze/thaw cycles in China based on Radiometer. - IOP Conference Series Earth and Environmental Science. https://doi.org/10.1088/17551315/17/1/012142.

[14] Han, Z., Deng, M., Yuan, A., Wang, J., Li, H., Ma, J. (2018): Vertical variation of a black soil's properties in response to freeze-thaw cycles and its links to shift of microbial community structure. - Science of the Total Environment 625: 106-113.

[15] Henry, A. (2007): Soil freeze-thaw cycle experiments: trends, methodological weaknesses and suggested improvements. - Soil Biology and Biochemistry 39: 977-986.

[16] Igun, O. T., Meynet, P., Davenport, R. J., Werner, D. (2019): Impacts of activated carbon amendments, added from the start or after five months, on the microbiology and outcomes of crude oil bioremediation in soil. - International Biodeterioration and Biodegradation 142: 1-10.

[17] Intergovernmental Panel on Climate Change, IPCC (2007): Climate Change 2007: The Physical Science Basis. - In: Solomon, S., Qin, D., Manning, M., Chen, Z., Marquis, M., Averyt, K. B. (eds.) Contribution of Working Group I to the Fourth Assessment Report of the Intergovernmental Panel on Climate Change. Cambridge University Press, Cambridge, UK and New York.

[18] Jia, J., Zong, S., Hu, L., Shi, S., Zhai, X., Wang, B. (2017): The dynamic change of microbial communities in crude oil-contaminated soils from oilfields in China. - Soil and Sediment Contamination 18: 1-30.

[19] Jiang, N., Juan, Y., Tian, L., Chen, X., Sun, W., Chen, L. (2018): Modification of the composition of dissolved nitrogen forms, nitrogen transformation processes, and diversity of bacterial communities by freeze-thaw events in temperate soils. - Pedobiologia Journal of Soil Ecology 71: 41-49.

[20] Juan, Y., Jiang, N., Tian, L., Chen, X., Sun, W., Chen, L. (2018): Effect of freeze-thaw on a midtemperate soil bacterial community and the correlation network of its members. - Biomed Research International 8412429: 1-13.

[21] Kimoto, M. (2005): Simulated change of the east Asian circulation under global warming scenario. - Geophysics Research Letters 32(16): 1-5.

[22] Koponen, H. T., Jaakkola, T., Keina, M. M. (2006): Microbial communities, biomass, and activities in soils as affected by freeze thaw cycles. - Soil Biology and Biochemistry 38: 1861-1871.

[23] Korenblum, E., Souza, D., Penna, M., Seldin, L. (2012): Molecular analysis of the bacterial communities in crude oil samples from two Brazilian offshore petroleum platforms. - International Journal of Microbiology 156537: 1-8.

[24] Kumar, N., Grogan, P., Chu, H., Christiansen, C. T., Walker, V. K. (2013): The effect of freeze-thaw conditions on arctic soil bacterial communities. - Biology (Basel) 2(1): 356377.

[25] Labbé, D., Margesin, R., Schinner, F., Whyte, L. G., Greer, C. W. (2007): Comparative phylogenetic analysis of microbial communities in pristine and hydrocarboncontaminated Alpine soils. - FEMS Microbiology Ecology 59(2): 466-475.

[26] Langille, M. G., Zaneveld, J., Caporaso, J. G., Mcdonald, D., Knights, D., Reyes, J. A., et al. (2013): Predictive functional profiling of microbial communities using 16S rRNA marker gene sequences. - Nature Biotechnology 31: 814-821.

[27] Li, W., Jiang, Z., Zhang, X., Li, L., Sun, Y. (2018): Additional risk in extreme precipitation in China from $1.5{ }^{\circ} \mathrm{C}$ to $2.0^{\circ} \mathrm{C}$ global warming levels. - Science Bulletin 63(4): 228-234.

[28] Lin, L., Wang, Z., Yang, Y., Zhang, H., Dong, W. (2018): Additional intensification of seasonal heat and flooding extreme over China in $2{ }^{\circ} \mathrm{C}$ warmer world compared to $1.5^{\circ} \mathrm{C}$. - Earths Future 6: 968-978. 
[29] Liu, Q., Tang, J., Gao, K., Gurav, R., Giesy, J. P. (2017): Aerobic degradation of crude oil by microorganisms in soils from four geographic regions of China. - Science Reports 7: 1-12.

[30] Meyer, B., Kuever, J. (2007): Molecular analysis of the diversity of sulfate-reducing and sulfur oxidizing prokaryotes in the environment, using aprA as functional marker gene. Applied Environmental Microbiology 73(23): 7664-7679.

[31] Okonkwo, C. J., Liu, N., Li, J., Ahmed, A. (2021): Experimental thawing events enhance petroleum hydrocarbon attenuation and enzymatic activities in polluted temperate soils. International Journal Environment Science and Technology. https://doi.org/10.1007/s13762-021-03175-8.

[32] Olsson, P. Q., Sturm, M., Racine, C. H., Romanovsky, V., Liston, G. E. (2003): Five stages of the Alaskan Arctic cold season with ecosystem implications. - Arctic, Antarctic and Alpine Research 35(1): 74-81.

[33] Peng, M., Zi, X., Wang, Q. (2015): Bacterial community diversity of oil-contaminated soils assessed by high throughput sequencing of $16 \mathrm{~S}$ rRNA genes. - International Journal of Environmental Research and Public Health 12(10): 12002-12015.

[34] R Core Team (2014): R: A language and Environment for Statistical Computing. - R Foundation for Statistical Computing, Vienna, Austria. URL http://www.R-project.org/.

[35] Ramadass, K., Smith, E., Palanisami, T., Mathieson, G., Srivastava, P., Megharaj, M., et al. (2015): Evaluation of constraints in bioremediation of weathered hydrocarboncontaminated arid soils through microcosm biopile study. - International Journal of Environmental Science and Technology 12(11): 3597-3612.

[36] Ren, J., Song, C., Hou, A., Song, Y., Zhu, X., Cagle, G. A. (2018): Shifts in soil bacterial and archaeal communities during freeze-thaw cycles in a seasonal frozen marsh, Northeast China. - Science of the Total Environment 625: 782-791.

[37] Schimel, J., Balser, T. C., Wallenstein, M. (2007): Microbial stress-response physiology and its implication. - Ecology 88(6): 1386-1394.

[38] Schmidhuber, J., Tubiello, F. (2007): The mixing phenomena of SLUSH hydrogen in ducts. - PNAS 104(50): 19703-19708.

[39] Shankar, V., Agans, R., Paliy, O. (2017): Advantages of phylogenetic distance based constrained ordination analyses for the examination of microbial communities. Scientific Reports 7: 1-10.

[40] Shen, R. C., Xu, M., Chi, Y. G., Yu, S., Wan, S. Q. (2014): Soil microbial responses to experimental warming and nitrogen addition in a temperate steppe of Northern China. Pedosphere 24(4): 427-436.

[41] Siles, J. A., Margesin, R. (2018): Insights into microbial communities mediating the bioremediation of hydrocarbon-contaminated soil from an Alpine former military site. Applied Microbiology and Biotechnology 102: 4409-4421.

[42] Skogland, T., Lomeland, S., Goksøyr, J. (1988): Respiratory burst after freezing and thawing of soil: experiments with soil bacteria. - Soil Biology and Biochemistry 20(6): 851-856.

[43] Sun, W., Li, J., Jiang, L., Sun, Z. (2015): Profiling microbial community structures across six large oilfields in China and the potential role of dominant microorganisms in bioremediation. - Applied Microbiology and Biotechnology 99(20): 8751-8764.

[44] Trellu, C., Mousset, E., Pechaud, Y., Huguenot, D., van Hullebusch, E. D., Esposito, G., et al. (2016): Removal of hydrophobic organic pollutants from soil washing/flushing solutions: a critical review. - Journal of Hazardous Materials 306: 149-174.

[45] Wang, Q., Garrity, G. M, Tiedje, J. M., Cole, J. R. (2007): Naïve Bayesian classifier for rapid assignment of rRNA sequences into the new bacterial taxonomy. - Applied Environmental Microbiology 73(16): 5261-5267.

[46] Wang, Q., Liu, J., Wang, L. (2017): An experimental study on the effects of freeze-thaw cycles on phosphorus adsorption-desorption processes in brown soil. - RSC Advances 7(59): 37441-37446. 
[47] White, T., Bruns, T. D., Lee, S. B., Taylor, J. W. (1990): Amplification and Direct Sequencing of Fungal Ribosomal RNA Genes for Phylogenetics. - Academic Press, Inc., Cambridge, MA, pp. 315-321.

[48] Wu, M., Dick, W. A., Li, W., Wang, X., Yang, Q., Wang, T., Wang, L., Chen, L. (2016): Bioaugmentation and biostimulation of hydrocarbon degradation and the microbial community in a petroleum-contaminated soil. - International Biodeterioration and Biodegradation 107: 158-64.

[49] Wu, M. L., Wu, J. L., Zhang, X. H., Ye, X. Q. (2019): Effect of bioaugmentation and biostimulation on hydrocarbon degradation and microbial community composition in petroleum-contaminated loessal soil. - Chemosphere 237: 124456.

[50] Wyszkowska, J., Kucharski, J. (2005): Correlation between the number of microorganisms and soil contamination with diesel oil. - Polish Journal of Environmental Studies 14: 359-368.

[51] Yang, S. Z., Jin, H. J., Wei, Z., He, R. X., Ji, Y. J., Li, X. M. (2019): Bioremediation of oil spills in cold environments: a review. - Pedosphere 19(3): 371-381.

[52] Zheng, Z., Zhang, Y., Su, X., Cui, X. (2016): Responses of hydrochemical parameters, community structures, and microbial activities to the natural biodegradation of petroleum hydrocarbons in a groundwater-soil environment. - Environmental Earth Science 75(21): 1400-1413.

\section{APPENDIX}
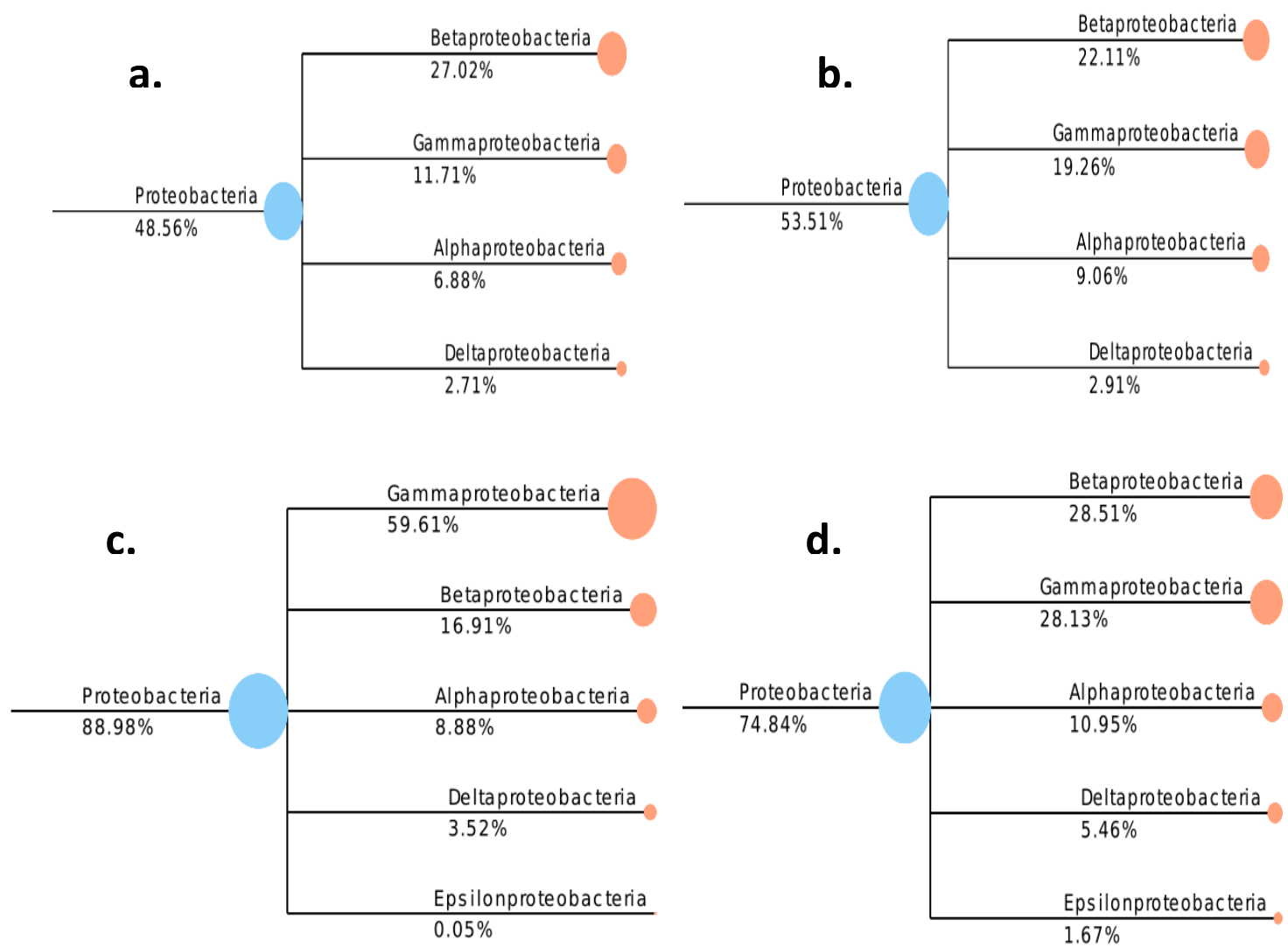

Figure A1. Bacterial class composition in (a) Clean natural soil CS (b) Diesel-oil amended soil SS1 (c) Crude-oil amended soil SS2 (d) weathered petroleum-polluted soil PS during Preincubation phase $\left(F-20^{\circ} \mathrm{C}\right)$ 

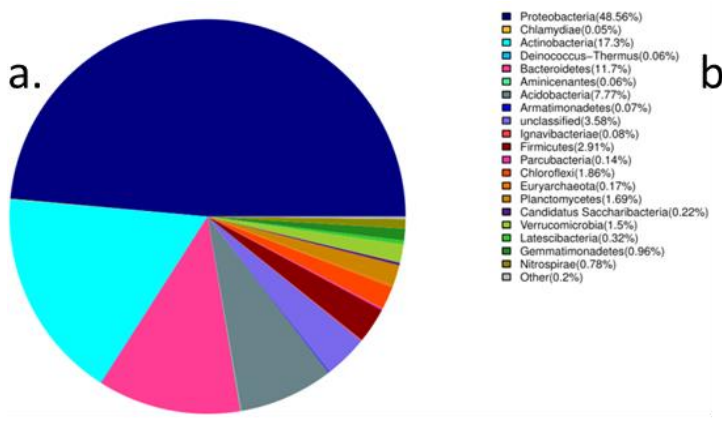

b.
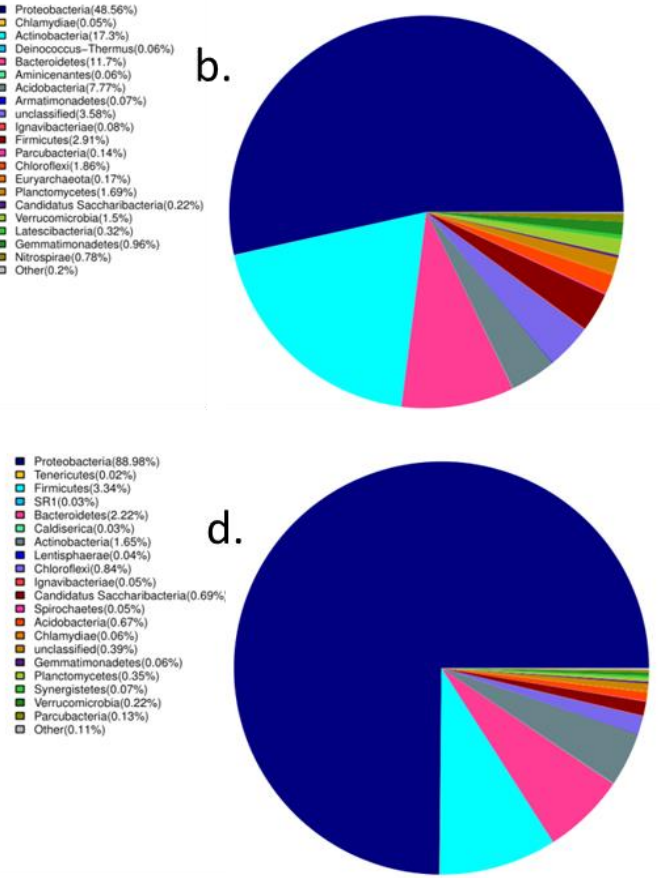
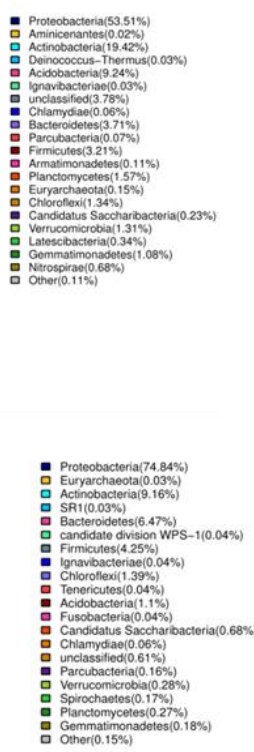

Figure A2. a-d Bacterial phylum composition in (a) Clean natural soil CS (b) Diesel-oil amended soil SS1 (c) Crude-oil amended soil SS2 (d) weathered petroleum-polluted soil PS at Pre-incubation phase $\left(F 20^{\circ} \mathrm{C}\right)$
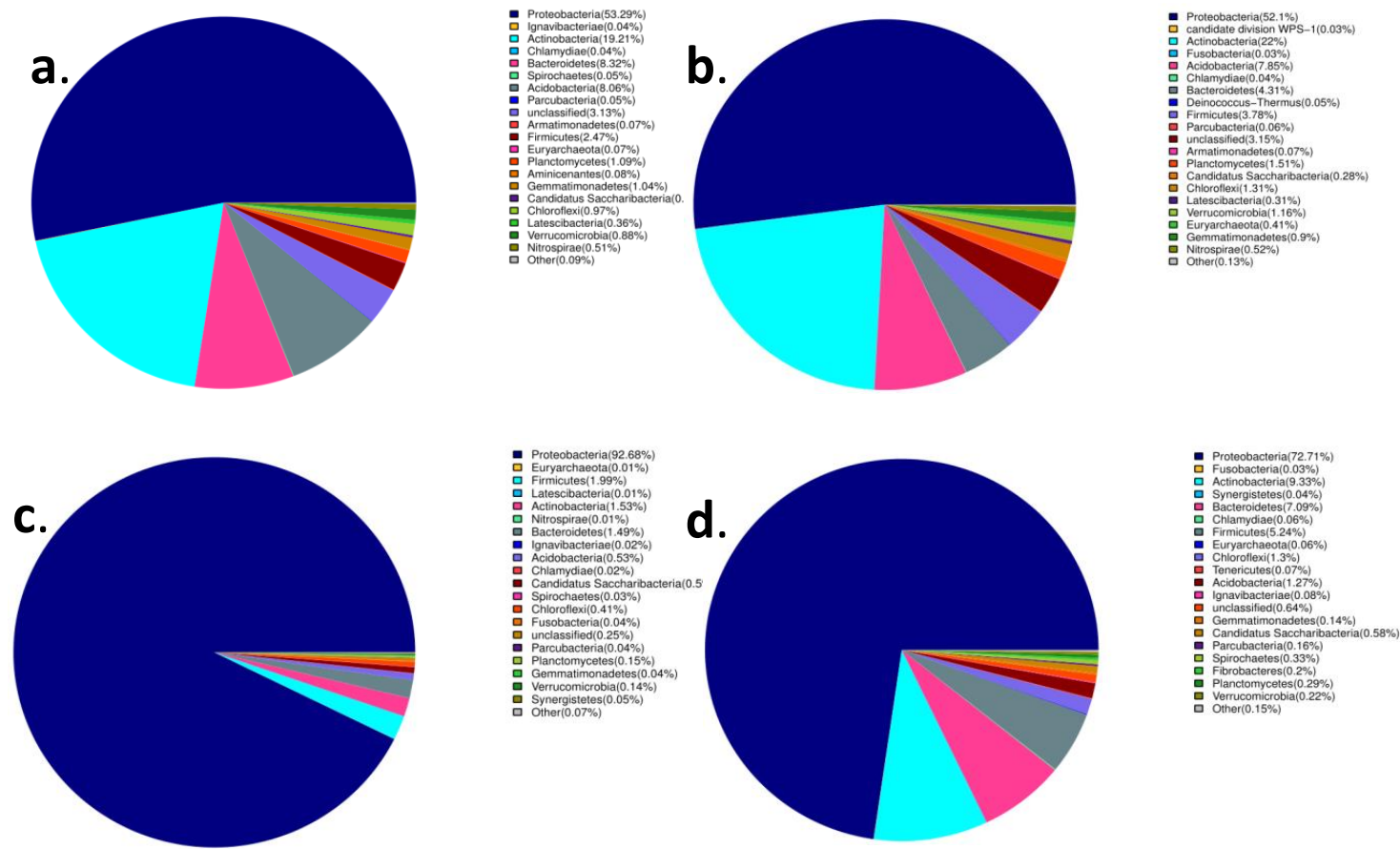

Figure A3. a-d Bacterial phylum composition in (a) Clean natural soil CS (b) Diesel-oil amended soil SS1 (c) Crude-oil amended soil SS2 (d) weathered petroleum-polluted soil PS at freezing phase $\left(F 10{ }^{\circ} \mathrm{C}\right)$ 
a.
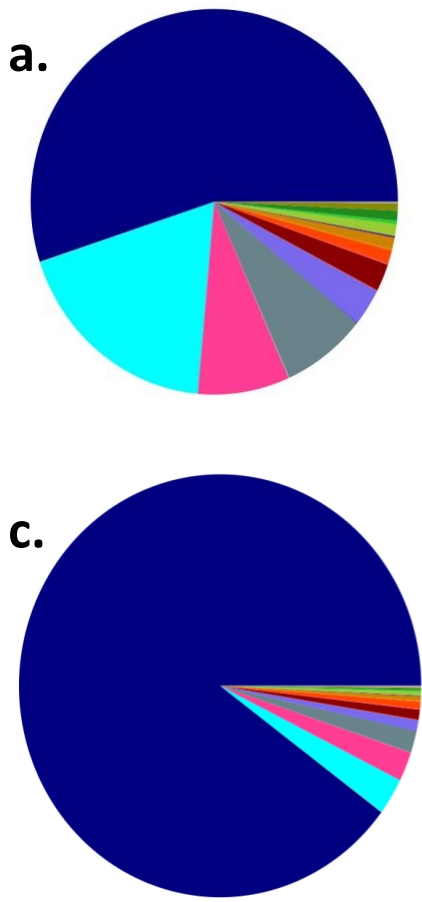

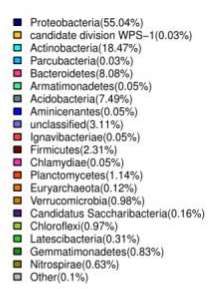

b.
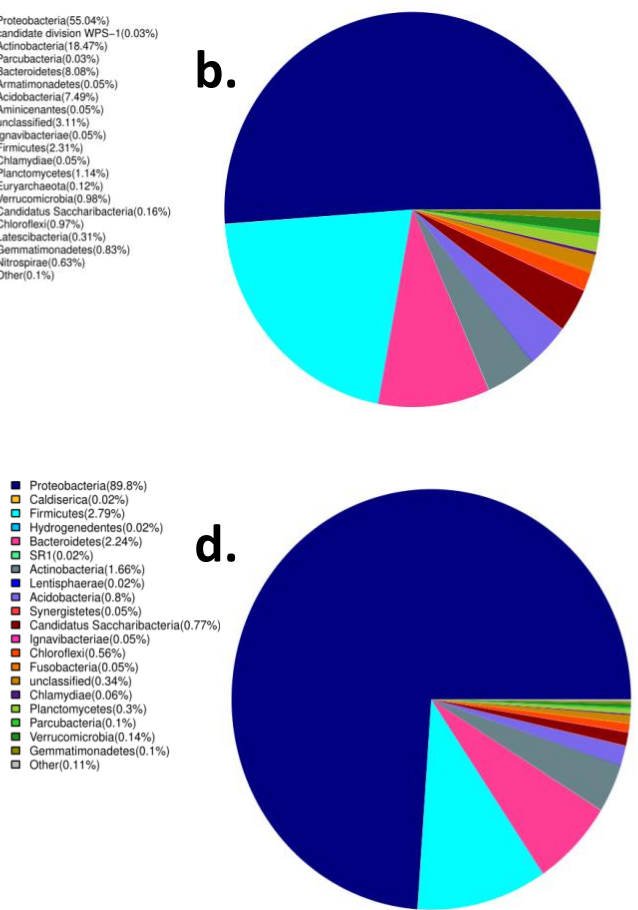
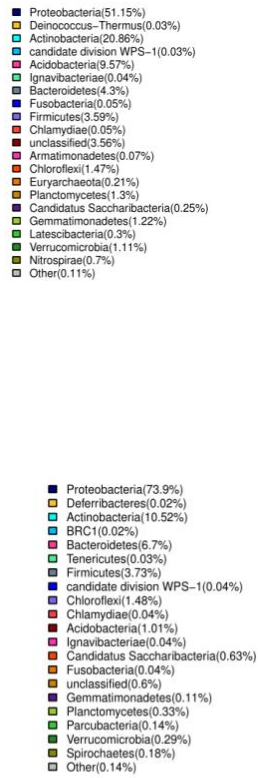

Figure A4. a-d Bacterial phylum composition in (a) Clean natural soil CS (b) Diesel-oil amended soil SS1 (c) Crude-oil amended soil SS2 (d) Weathered petroleum-polluted soil PS at freezing phase $\left(\mathrm{FO}{ }^{\circ} \mathrm{C}\right)$
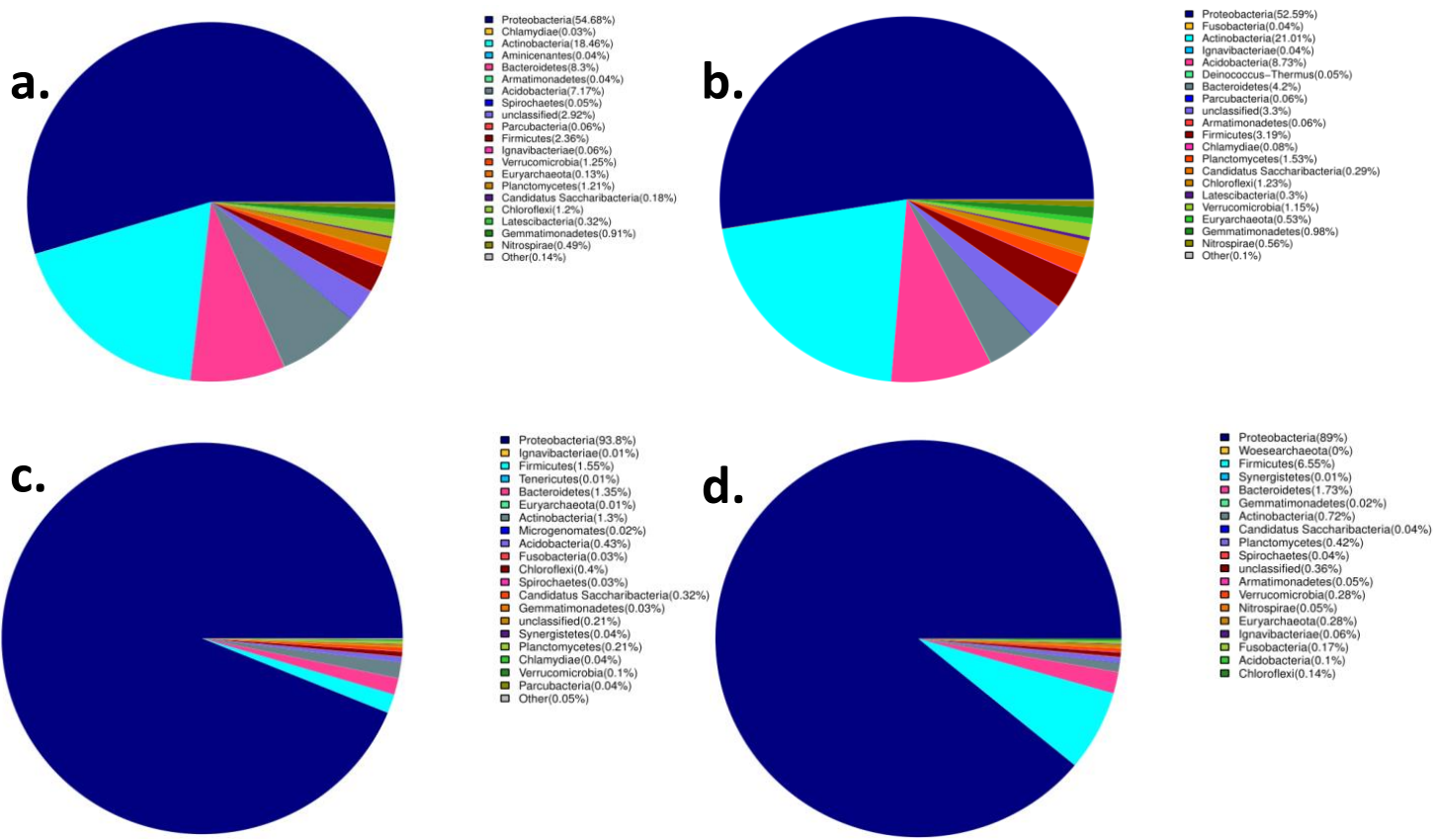

Figure A5. a-d Bacterial phylum composition in (a) Clean natural soil CS (b) Diesel-oil amended soil SS1 (c) Crude-oil amended soil SS2 (d) Weathered petroleum-polluted soil PS at freezing phase $\left(F-10^{\circ} \mathrm{C}\right)$ 
a.
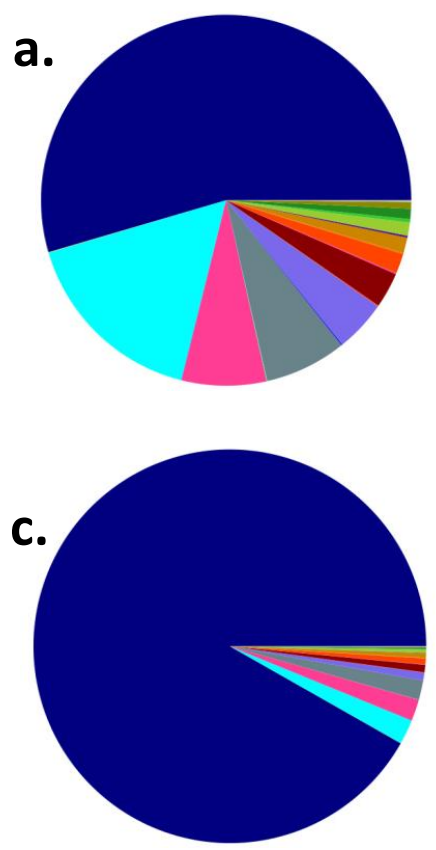
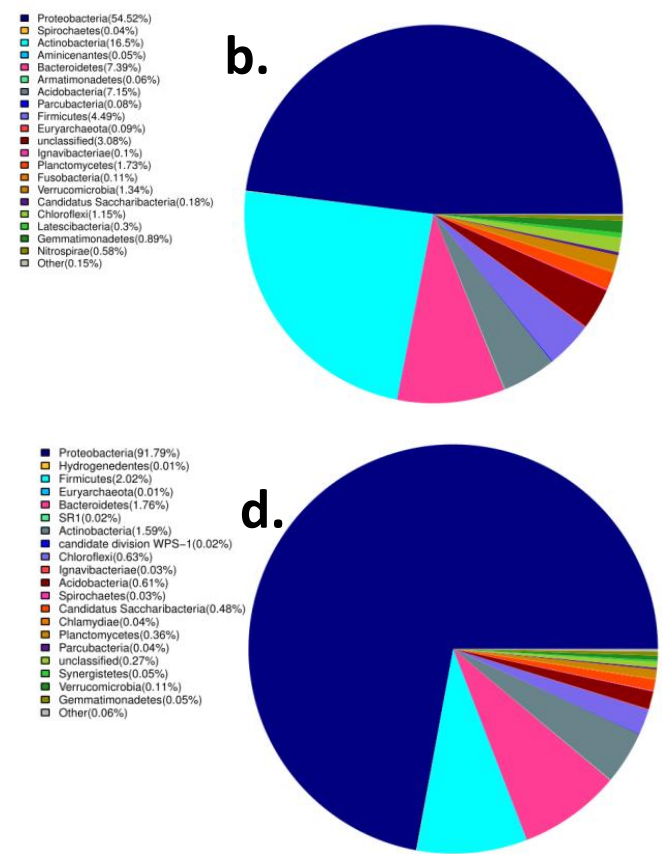
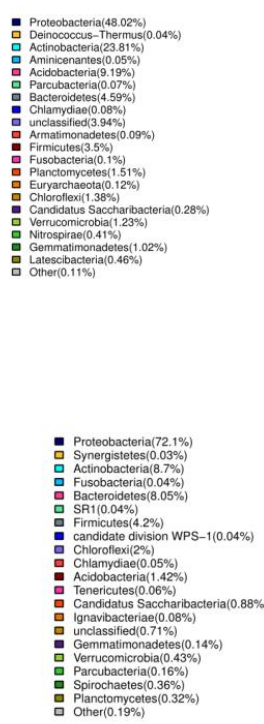

Figure A6. a-d Bacterial phylum composition in (a) Clean natural soil CS (b) Diesel-oil amended soil SS1 (c) Crude-oil amended soil SS2 (d) Weathered petroleum-polluted soil PS at freezing phase $\left(F-20^{\circ} \mathrm{C}\right)$
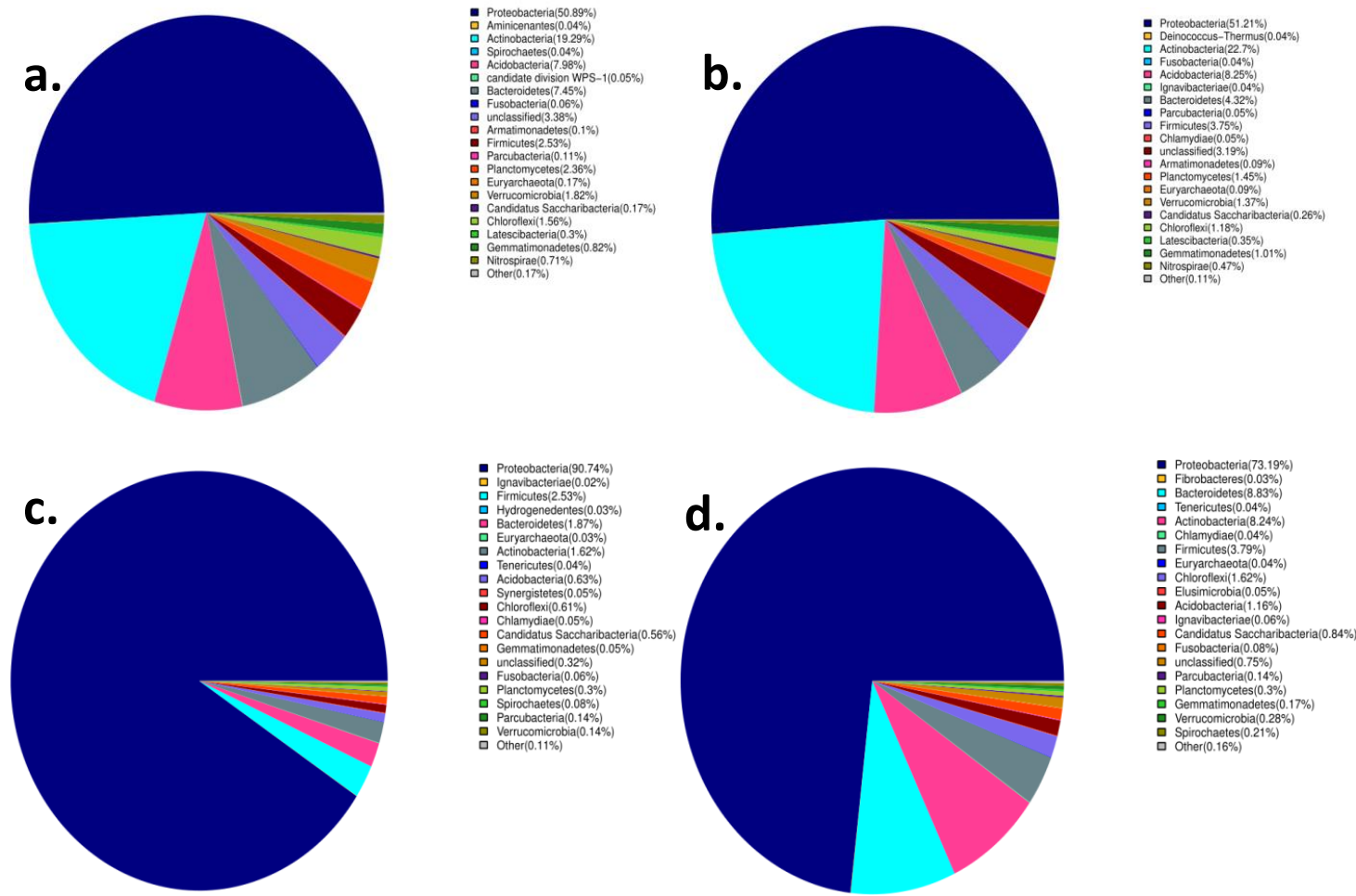

Figure A7. a-d Bacterial phylum composition in (a) Clean natural soil CS (b) Diesel-oil amended soil SS1 (c) Crude-oil amended soil SS2 (d) Weathered petroleum-polluted soil PS at transition phase $\left(T-20^{\circ} \mathrm{C}\right)$ 
a.
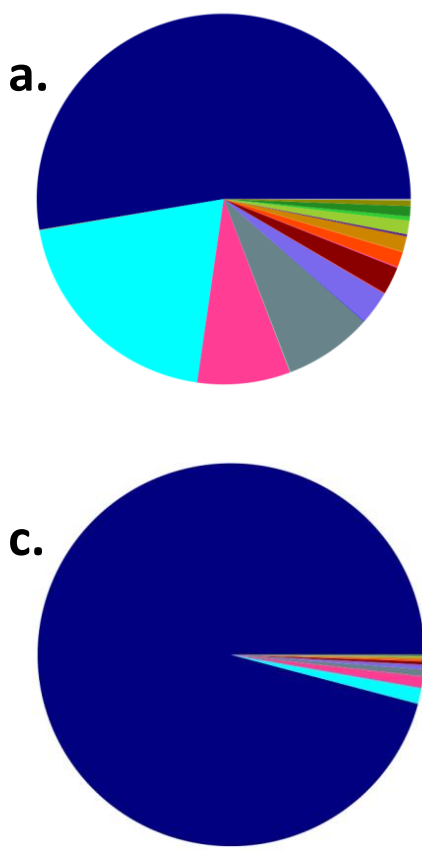

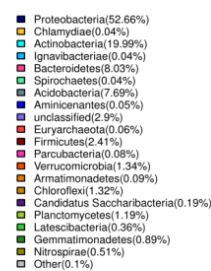

b.
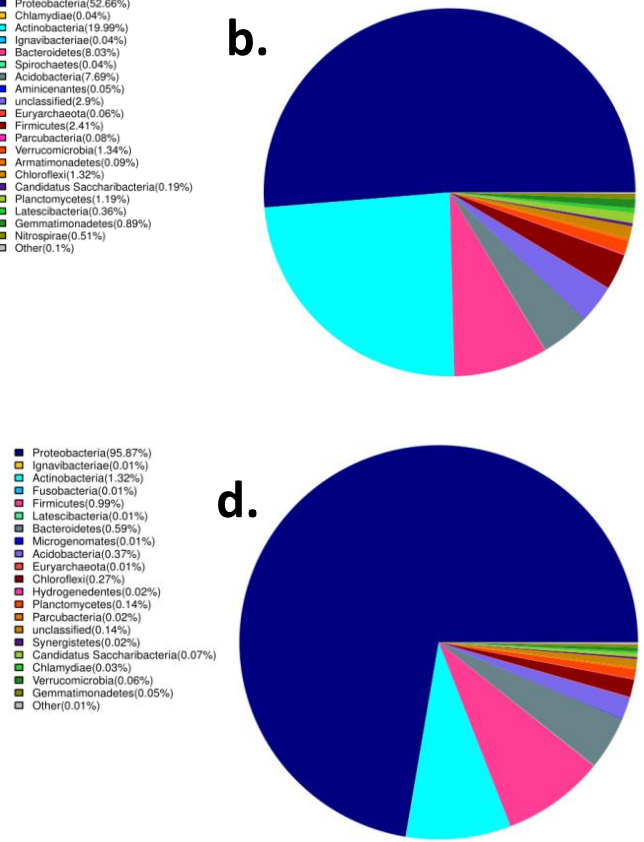
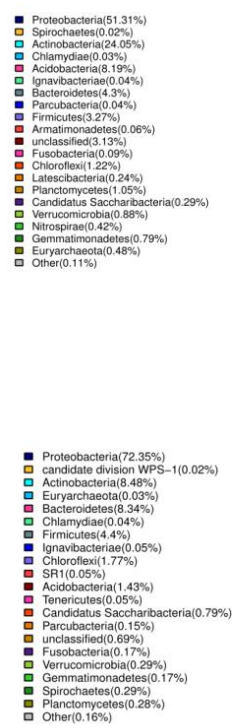

Figure A8. a-d Bacterial phylum composition in (a) Clean natural soil CS (b) Diesel-oil amended soil SS1 (c) Crude-oil amended soil SS2 (d) Weathered petroleum-polluted soil PS at thawing phase $\left(T-10^{\circ} \mathrm{C}\right)$
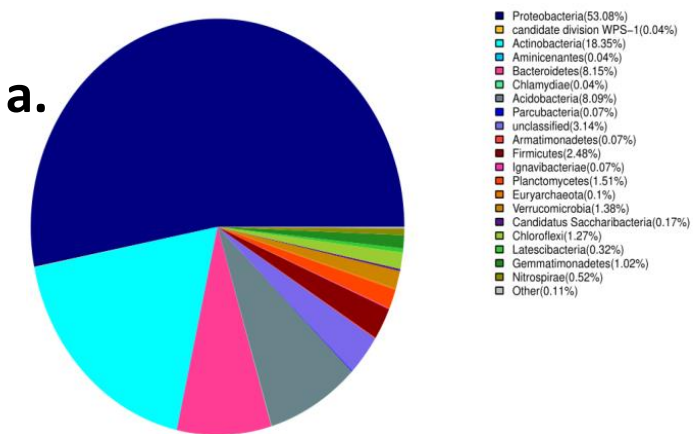

b.
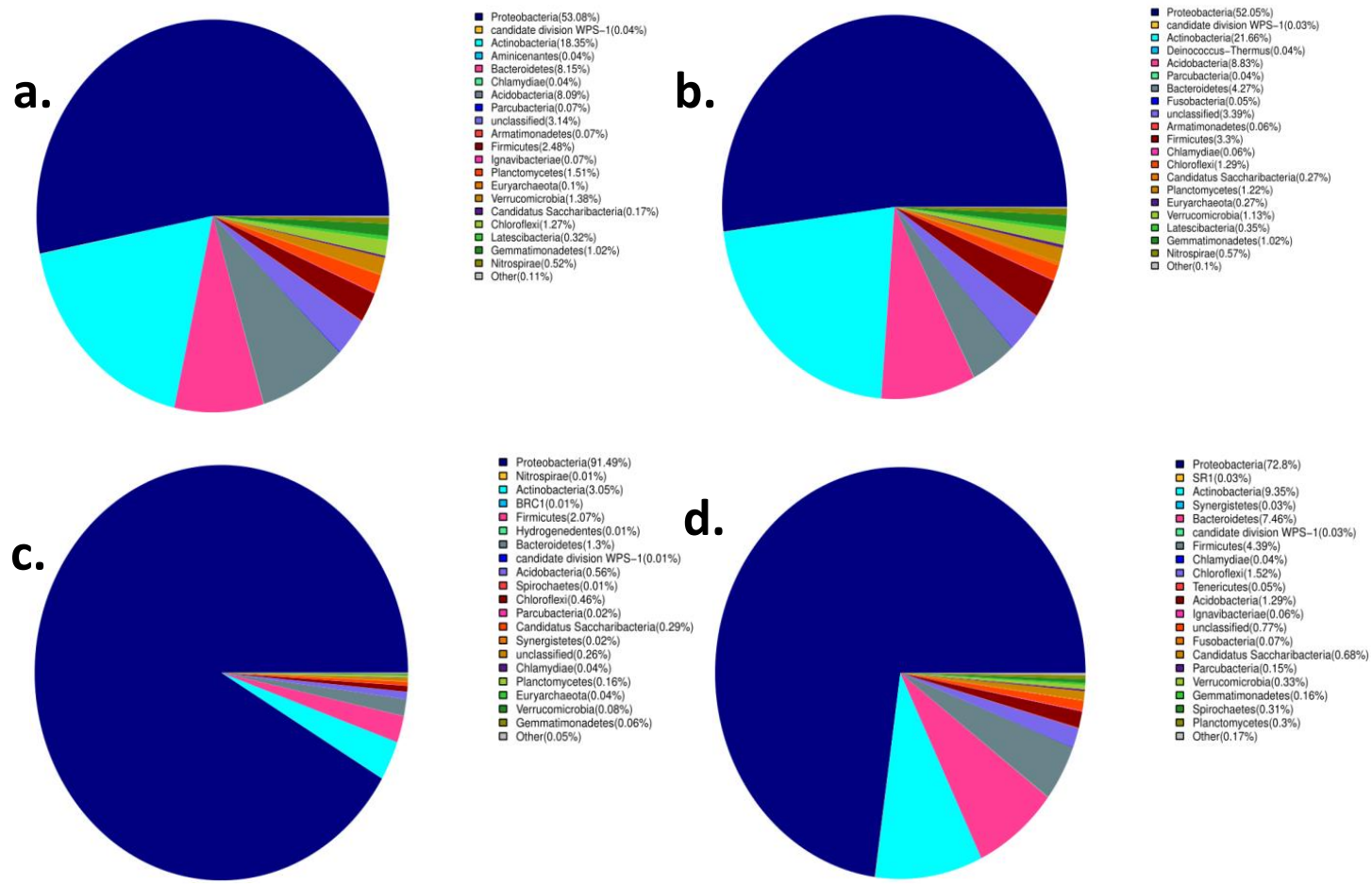

Figure A9. a-d Bacterial phylum composition in (a) Clean natural soil CS (b) Diesel-oil amended soil SS1 (c) Crude-oil amended soil SS2 (d) Weathered petroleum-polluted soil PS at thawing phase $\left(\mathrm{TO}^{\circ} \mathrm{C}\right)$ 

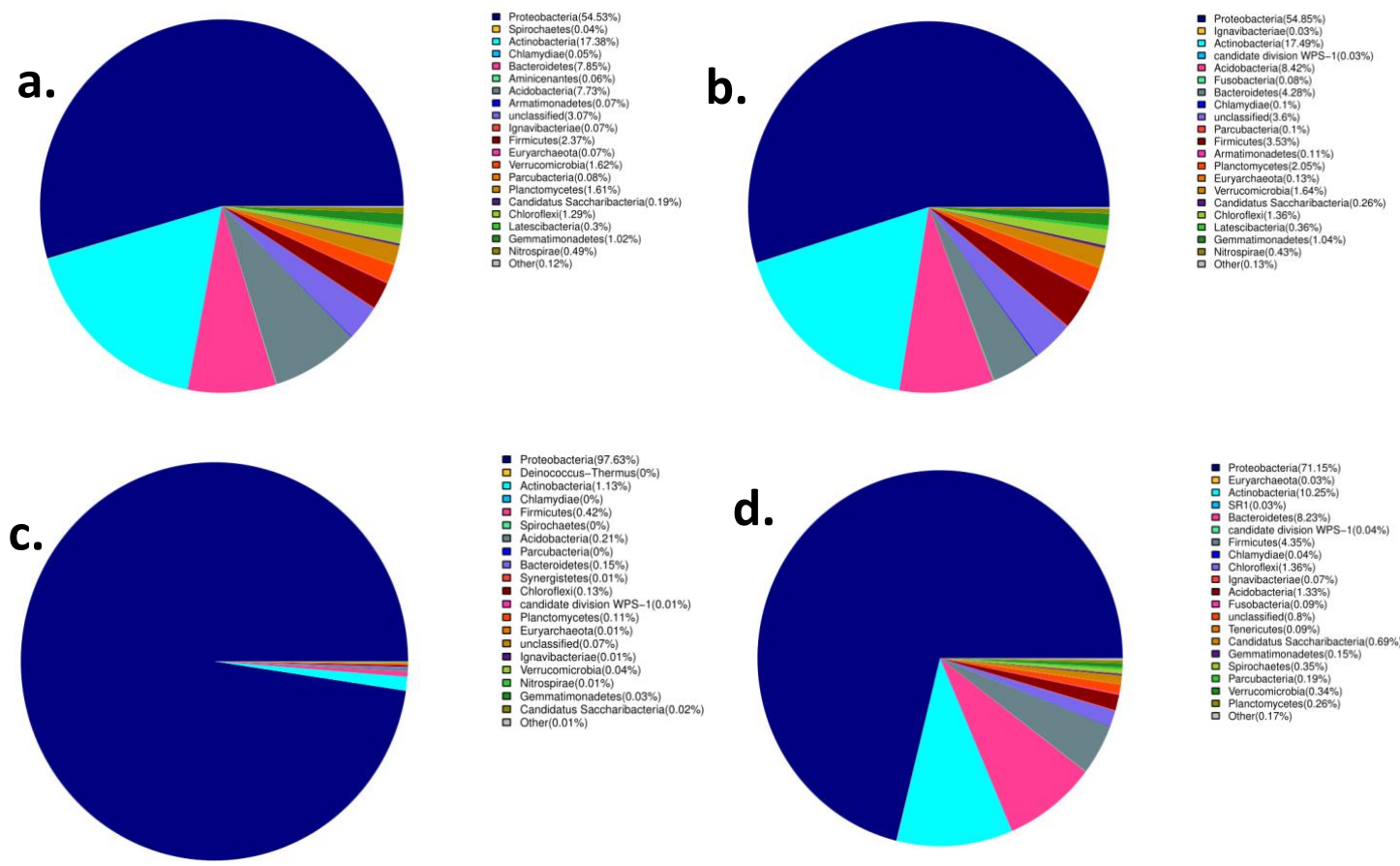

Figure A10. a-d Bacterial phylum composition in (a) Clean natural soil CS (b) Diesel-oil amended soil SS1 (c) Crude-oil amended soil SS2 (d) Weathered petroleum-polluted soil PS at thawing phase $\left(T 10{ }^{\circ} \mathrm{C}\right)$

a.

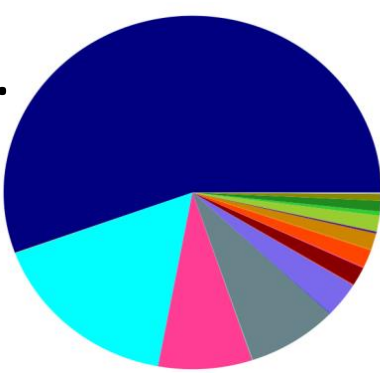

c.

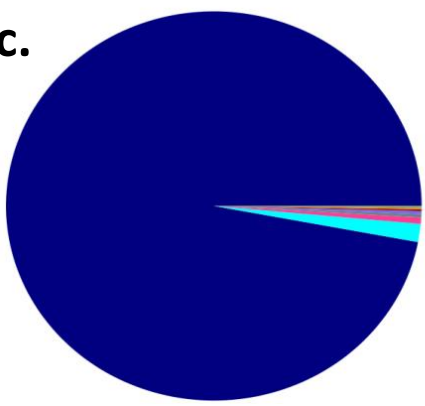

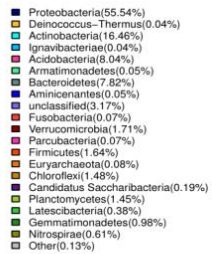

b.
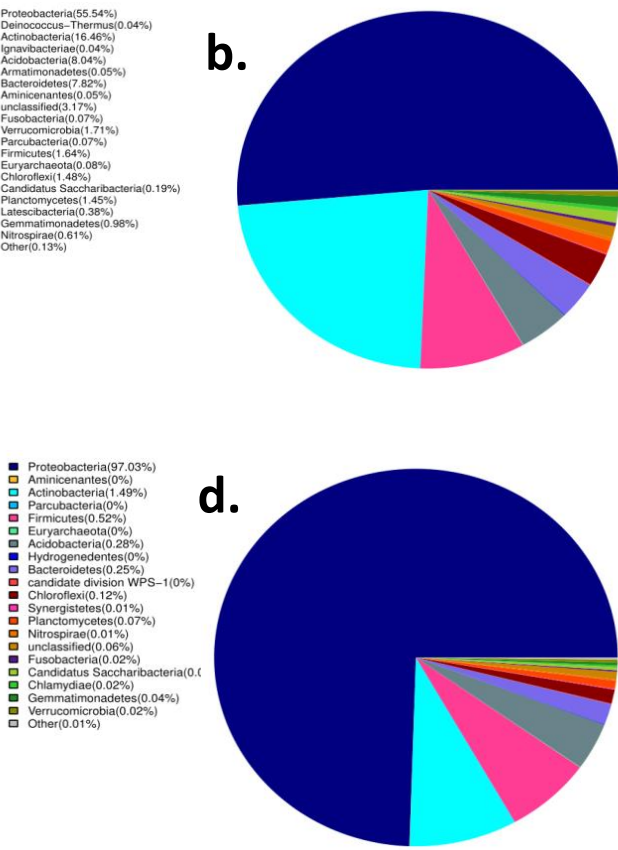
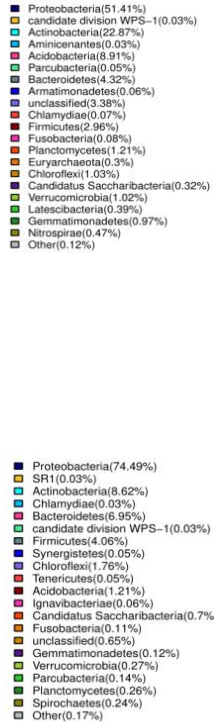

Figure A11. a-d Bacterial phylum composition in (a) Clean natural soil CS (b) Diesel-oil amended soil SS1 (c) Crude-oil amended soil SS2 (d) Weathered petroleum-polluted soil PS at thawing phase $\left(T 20^{\circ} \mathrm{C}\right)$ 


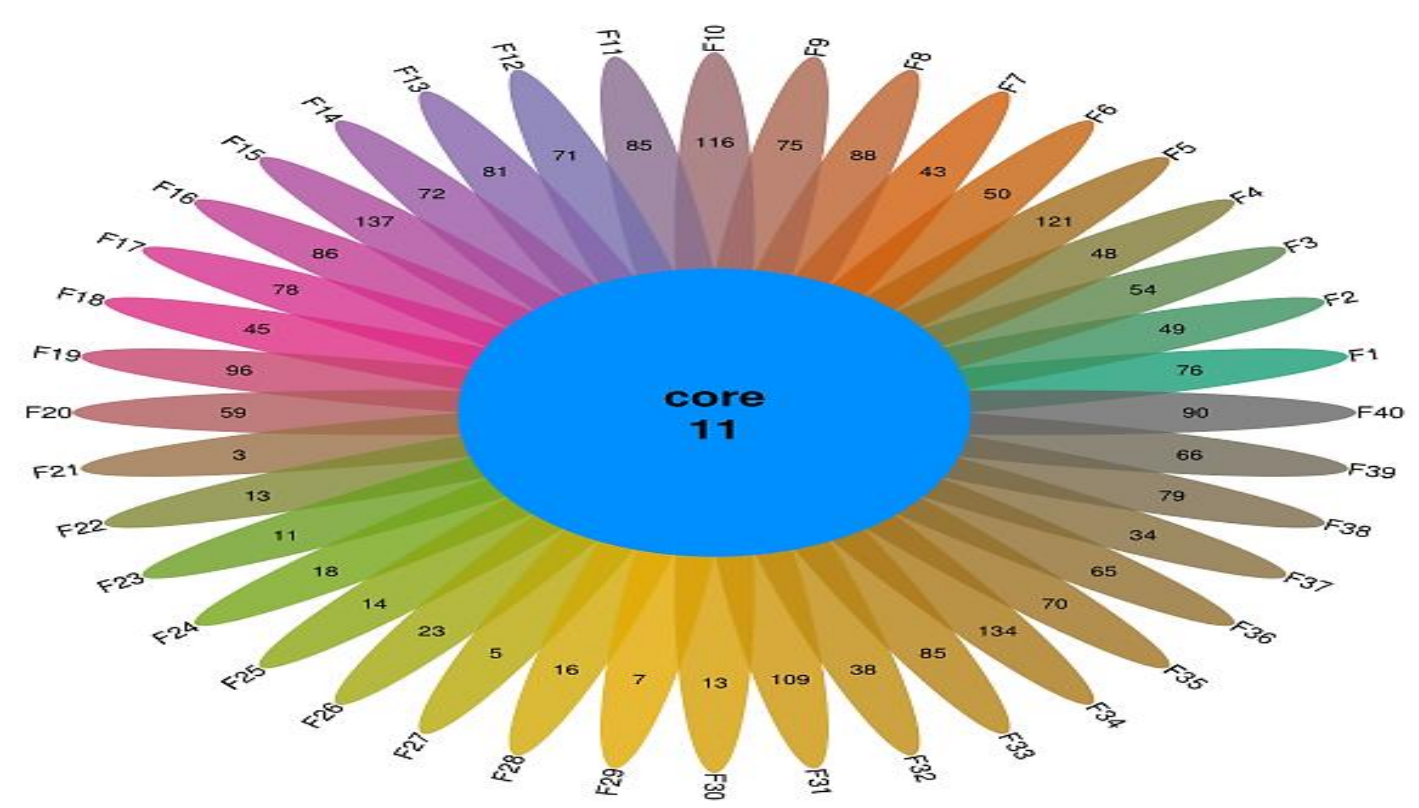

Figure A12. Venn diagram showing the unique bacterial species in the soil samples CS, SS1, SS2 and PS. F1: CS, F11: SS1, F21: SS2, F31: PS (F $20^{\circ} \mathrm{C}$, Pre-incubation phase). F2: CS, F12: SS1, F22: SS2, F32: PS (F $10{ }^{\circ} \mathrm{C}$, Freezing phase). F3: CS, F13: SS1, F23: SS2, F33: PS (F $0{ }^{\circ} \mathrm{C}$, Freezing phase). F4: CS, F14: SS1, F24: SS2, F34: PS (F-10 ${ }^{\circ} \mathrm{C}$, Freezing phase). F5: CS, F15: SS1, F25: SS2, F35: PS (F-20 ${ }^{\circ} \mathrm{C}$, Freezing phase). F6: CS, F16: SS1, F26: SS2, F36: PS (T-10 ${ }^{\circ} \mathrm{C}$, Transition phase). F7: CS, F17: SS1, F27: SS2, F37: PS (T $0{ }^{\circ} \mathrm{C}$, Thawing phase). F8: CS, F18: SS1, F28: SS2, F38: PS (T0 ${ }^{\circ} \mathrm{C}$, Thawing phase). F9: CS, F19: SS1, F29: SS2, F39: PS (T $0{ }^{\circ} \mathrm{C}$, Thawing phase). F10: CS, F20: SS1, F30: SS2, F40: PS $\left(T 0{ }^{\circ} \mathrm{C}\right.$, Thawing phase) 